\title{
Prodrugs available on the Brazilian pharmaceutical market and their corresponding bioactivation pathways
}

\author{
Roberto Parise Filho'*, Michelle Carneiro Polli², Silvio Barberato Filho ${ }^{3}$, Monique Garcia ${ }^{1}$, \\ Elizabeth Igne Ferreira ${ }^{4}$
}

\begin{abstract}
${ }^{1}$ Department of Pharmacy, Center for Health and Biological Sciences, Mackenzie Presbyterian University, ${ }^{2}$ Department of Pharmacy, São Francisco University, ${ }^{3}$ Department of Pharmacy, Sorocaba University, ${ }^{4}$ Department of Pharmacy, Faculty of Pharmaceutical Sciences, University of São Paulo
\end{abstract}

\begin{abstract}
The aim of this paper was to emphasize the importance of prodrug design to therapy, by examining examples available on the Brazilian pharmaceutical market. The principles of prodrug design are briefly discussed herein. Examples of prodrugs from many important therapeutic classes are shown and their advantages relative to the drugs they are derived from are also discussed. Considering the importance of these therapeutic classes, from both therapy and economic standpoints, prodrug design is a very valuable aspect in the research of new drugs and for the pharmaceutical industry as a whole.
\end{abstract}

Uniterms: Prodrug design. Molecular modification. Drug development.

O objetivo do trabalho foi ressaltar a importância do planejamento de pró-fármacos para a terapia, por meio de exemplos disponíveis no mercado farmacêutico brasileiro. Os princípios da latenciação são sucintamente discutidos. Apresentam-se exemplos de pró-fármacos de muitas classes terapêuticas importantes e as vantagens relativas aos fármacos dos quais derivam são, também, discutidas. Considerando-se a importância dessas classes terapêuticas, tanto do aspecto terapêutico quanto do econômico, o planejamento de pró-fármacos representa aspecto de grande valor na busca de novos fármacos e na indústria farmacêutica como um todo.

Uniterms: Pró-fármacos/planejamento Fármacos/latenciação. Modificação molecular. Fármacos/ desenvolvimento.

\section{INTRODUCTION}

Currently, several tools are available for researching chemical entities aimed at introducing new pharmaceuticals for use in therapy. Among the different strategies employed, molecular modification deserves special mention. This approach entails the structural alteration of a known and previously characterized lead compound. The starting molecule is called a prototype, whilst the derivatives obtained from the prototype are classified as either analogues or prodrugs, depending on the type of molecular modification executed. Molecular modification can have different aims with the main objectives being:

\footnotetext{
"Correspondence: R. Parise Filho. Department of Pharmacy, Center for Health and Biological Sciences, Mackenzie Presbyterian University. Rua da Consolação, 930 - Consolação - 01302-907 - São Paulo - SP, Brasil. E-mail: parisi@mackenzie.br
}

the acquisition of substances with superior pharmaceutical properties compared to those of the prototype, the discovery of a pharmacophoric group, or the study of the relationship between a chemical structure of a compound and its biological activity (Korolkovas, Burckhalter, 1988; Patani, Lavoie, 1996; Wermuth, 2006).

The molecular modification strategy is widely employed in the research and development of new drugs. Considering that this strategy involves use of a compound with previously known biological activity, the biological experiments to be executed with the new derivatives consist of routine, and hence less complex, studies. Molecular modification enables the optimization of compounds that have previously been marketed and have presented pharmacokinetic or toxicity issues. Furthermore, it is important to mention that the rate of success in the acquisition of a new chemical entity is greater when the structure of a pro- 
totype with a proven biological property is used (Ettmayer et al., 2004; Barreiro, Fraga, 2008).

As mentioned previously, molecular modification may give rise to compounds called prodrugs. This process is known as drug latentiation (Figure 1).

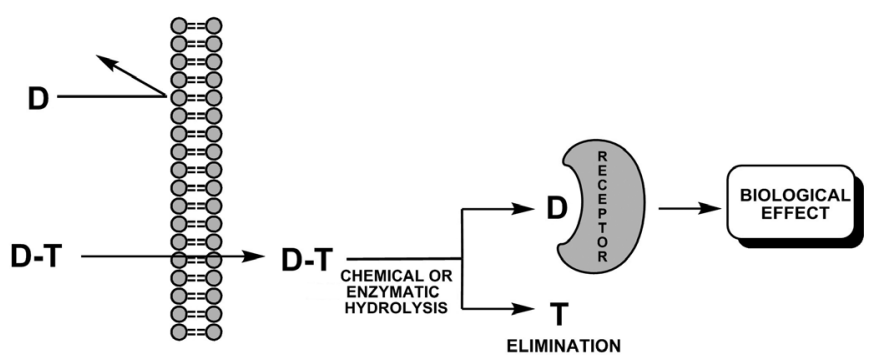

FIGURE 1 - Diagram of the latentiation process. (D: drug, $\mathrm{T}$ : transporter group, D-T: prodrug) Adapted from Friis and Bundgaard(1996).

Latentiation may be defined as the chemical union between a drug and a "transporter group", normally by means of a covalent labile bond, giving rise to the classical concept of a prodrug. It is a temporarily inactive compound that, once inside the organism, needs to be metabolized to attain its active form (Bundgaard, 1985; Bundgaard, 1991; Chung et al., 2005; Liederer, Borchardt, 2006; Parise-Filho et al., 2007; Rautio et al., 2008; Silva et al., 2005; Stella, 2004; Wermuth, 2006).

The term latentiation was first used to describe inactive compounds that required biotransformation before they could carry out their biological function (Albert, 1958; Harper, 1959). The compounds covered by this designation, known as prodrugs, are inactive by nature, and as such are not designed to function (Stella et al., 1985). Some long-known compounds provide examples of prodrugs, notwithstanding the fact that they were discovered before the concept of latentiation. One such example is codeine (Figure 2), isolated in the 19th Century. It was observed that this compound was converted into morphine when administered in vivo (Ettmayer et al., 2004; Santos, 2008).

In 1897, Felix Hoffmann employed the latentiation principal when he modified the structure of salicylic
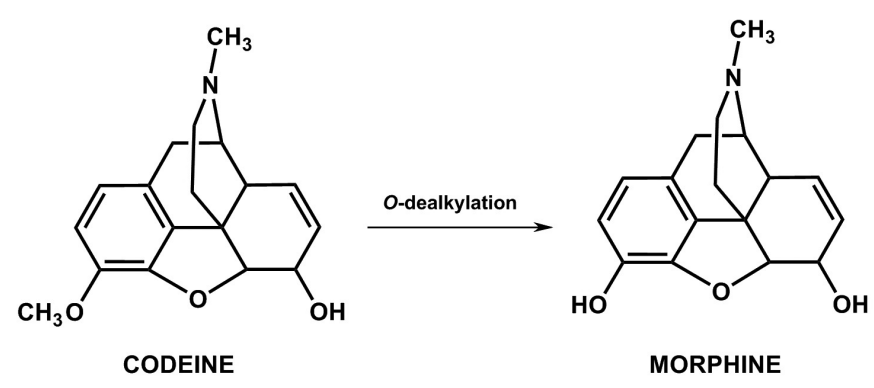

FIGURE 2 - Biotransformation of codeine, with the consequent release of morphine in vivo.

acid and obtained acetylsalicylic acid (Figure 3), with the aim of reducing its irritating effects on the stomach (Chung, Ferreira, 1998). However, it is known that acetylsalicylic acid acts per se, on cyclooxygenases 1 and 2 by means of acylation, as well as being active after the release of salicylic acid, whose properties are analogous to its derivative. It could therefore be considered a hybrid analogue-prodrug structure, like some other examples used in therapy.

It was only from the 1970s onwards that the concept emerged of designing prodrugs to modify the non-ideal physical-chemical properties of certain compounds, thus making them more efficient (Stella, Nti-Addae, 2007). Accordingly, the latentiation method has since been employed by pharmaceutical chemists in the development of pharmaceuticals because it enables the improvement of several undesirable properties of a prototype without however, altering its biological effectiveness (Han, Amidon, 2000; Wermuth, 2006).

Because it causes changes in physical-chemical properties, the latentiation method is usually employed to resolve issues pertaining to the transport of drugs within the organism, whether by increasing their rate of absorption through cellular barriers, regulating their retention time within the organism (Han, Amidon, 2000; Shan et al., 1997; Wermuth, 1984) or even by directing the drug to a specific location, a situation in which they are classified as directed drugs. These are highly selective latent types,

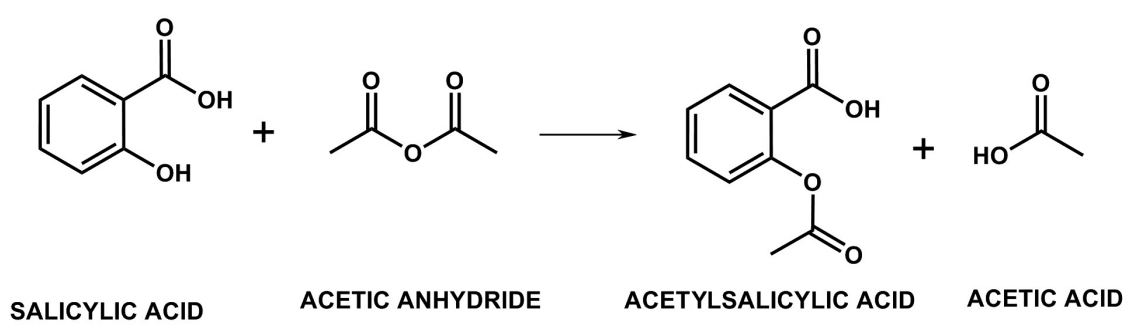

FIGURE 3 - Reaction of salicylic acid with acetic anhydride for the acquisition of acetylsalicylic acid and the release of acetic acid (the principal of latentiation). 


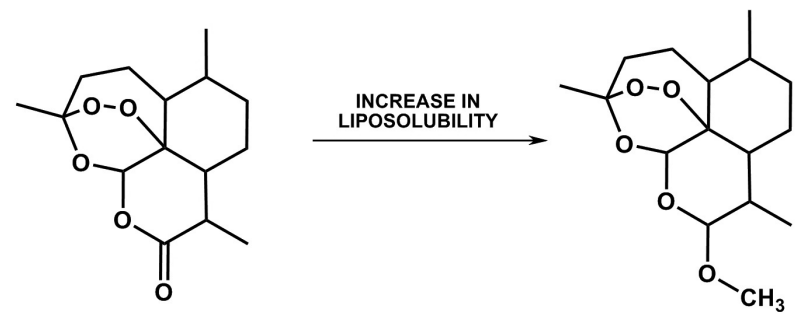

ARTEMISININ

ARTEMETER

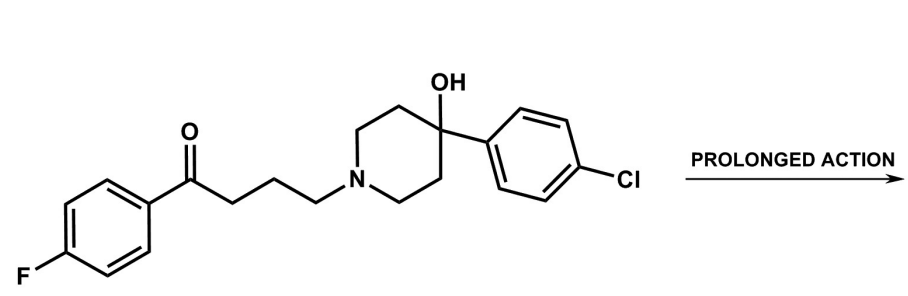

HALOPERIDOL<smiles>CCCCC(C)(C)OC(=O)C1(c2ccc(Cl)cc2)CCN(CCCC(=O)c2ccc(F)cc2)CC1</smiles>

HALOPERIDOL DECANOATE

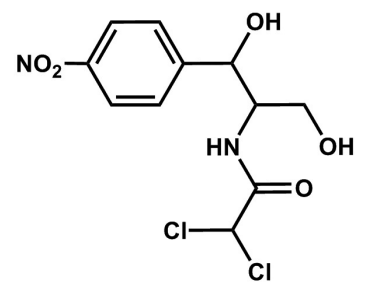

CHLORAMPHENICOL

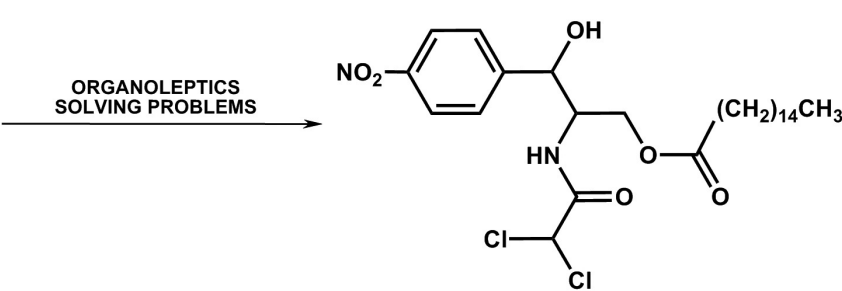

CHLORAMPHENICOL PALMITATE

FIGURE 4 - Examples of prodrugs and their respective purposes.

and form the basis of advanced forms of drug transporters (Chung et al., 2005; Silva et al., 2005). Based on these facts, the first step in latentiation comprises establishing the nature of the problem the drug presents. Such problems include: (1) instability or inadequate solubility in the formulation or when in contact with gastrointestinal fluids; (2) undesirable organoleptic characteristics; (3) inadequate hydrolipophilic equilibrium to pass through biological membranes, thus leading to a reduction in the rate of absorption; (4) drug toxicity; (5) high rate of biotransformation or pre-systemic elimination; (6) low functional specificity (Blau et al., 2006; Chung et al., 2005; Silva et al., 2005; Taylor, 1996). Consequently, the purpose of designing a prodrug is to provide solutions to all the above-mentioned problems.

The examples in Figure 4 illustrate cases in which it was possible to design prodrugs to resolve inherent issues in some drugs.

The first example shows an increase in the liposolubility of an antimalarial drug by replacing the carbonyl group with the methoxy group. In this case, the increase in liposolubility facilitates the passage of the drug through the blood-brain barrier, thus making it useful in the treatment of cerebral malaria. The next drug, haloperidol, had its hydroxyl masked by the formation of an ester bond with decanoic acid, giving a consequential increase in liposolubility. This alteration in solubility led to the acquisition of a longer-acting, intra-muscularly applied, haloperidol derivative that releases the drug gradually into the organism. In the next example, chloranfenicol was esterified, by means of its primary hydroxyl group, upon reaction with palmitic acid, also resulting in increased liposolubility. Thus, the alteration in solubility of chloramphenicol reduced the dissolution of the drug in patients' mouths, hence masking its bitter flavor (Chung et al., 2005).

Latentiation as a method of developing new drugs has been attracting increasing interest (Testa, 2004). In 1985, Stella et al., questioned whether prodrugs presented any advantages in clinical practice. Six years later, in 1991, Hiller answered this question: $20 \%$ to $30 \%$ of drugs introduced into therapy between 1986 and 1991 were developed with the latentiation method. More recent data indicates that approximately $15 \%$ of new drugs approved during the 2001-02 period comprised prodrugs (Rautio et al., 2008). 
Considering the importance of molecular modification of drugs as a source for the acquisition of new compounds and given that the latentiation of drugs is an important tool for this modification, this study aimed to prove, by means of the prodrugs available for use in therapy in Brazil, the real value of this process in the introduction of new drugs into clinical medicine. This review is based on the classification proposed by Wermuth (1984), which proposes the classification of latent forms into prodrugs and directed drugs. Wermuth classified the former into the following categories: classic, bioprecursors, reciprocal and mixed. The prodrugs, in their different categories, are the main focus of this study.

\section{PRODRUGS IN THERAPY}

\section{Bioprecursors}

Bioprecursors are latent forms that require biotransformation, generally by means of oxy-reduction mechanis$\mathrm{ms}$, with the aim of producing an active metabolite. These are compounds without a transporter group and several examples of prodrugs available for use in therapy in Brazil are classified as bioprecursors (Ettmayer et al., 2004).

\section{Antivirals}

Acyclovir, marketed under several pharmaceutical brandnames (Carneiro França, 2008), is a nucleoside analogue with an inhibiting function against the human herpes virus, including Herpes simplex (VHs) virus, types
1 and 2, Varicella zoster (VVZ) virus, Epstein Barr (VEB) virus and cytomegalovirus (CMV). It was discovered by triage and introduced onto the market in 1981. It represents an evolution in the treatment of herpes, as it was the first relatively safe and non-toxic drug to be used systemically (Ettmayer et al., 2004; Patrick, 2005). In infected cells, the agent undergoes phosphorylation in three stages, thus generating an active triphosphate compound. Because it requires oxidative bioactivation, acyclovir is considered a bioprecursor prodrug. Figure 5 illustrates the mono-, bi- and triphosphorylation stages of acyclovir.

It is important to emphasize that acyclovir only undergoes triphosphorylation in infected cells. It more readily undergoes first step phosphorylation with viral thymidine kinase $(100 \mathrm{x})$ than by the same enzyme in non-infected cells. Therefore, in normal cells, acyclovir is a poor substrate for cellular thymidine kinase, as it does not become active for these cells. This, together with the fact that selective capturing of acyclovir by infected cells occurs, explains its excellent effectiveness and low toxicity (Patrick, 2005; Steingrimsdottir et al., 2000).

It should be noted that all antiviral drug nucleoside analogues, such as gancyclovir and pencyclovir, that present an open saccharide portion, require triphosphorylation in order to execute their antiviral function and thus are analog bioprecursors. In the same context, several antiretroviral drugs (Figure 6) such as zidovudine, estavudine, didanosine, lamivudine, zalcitabine (Carneiro França, 2008) and entricitabine, not yet available on the Brazilian market, that present a similar bioactivation mechanism,
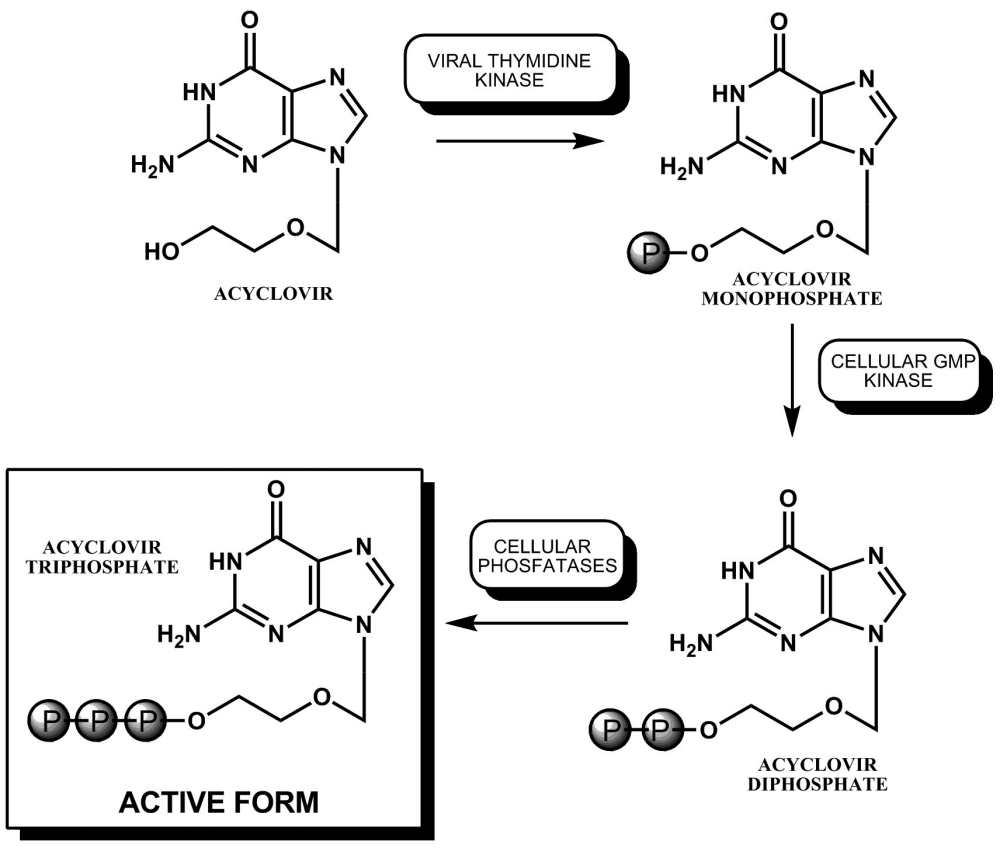

FIGURE 5 - Diagram of acyclovir bioactivation into acyclovir trisphosphate. GMP-guanosine monophosphate. 
are considered bioprecursor prodrugs (De Clercq, 2002, 2004; Otto, 2004).

\section{Antilipemic Agents}

Currently, high levels of cholesterol associated with other risk factors have led to serious repercussions in the quality of life of the world's population. Thus, imminent risks regarding the development of cardiovascular diseases have aroused great interest on the part of the pharmaceu- tical industries, resulting in the search for new therapeutically useful agents.

Statins (Carneiro França, 2008) are hypocholesterolemic drugs discovered in the 1970s that are currently the blockbusters of the pharmaceutical industry, topping one billion dollars in sales. Statins are capable of inhibiting 3-hydroxy-3-methylglutaryl-CoA reductase (HMGCo-A reductase - HMGR), a fundamental enzyme in the cholesterol biosynthetic pathway (Figure 7). This enzyme<smiles>CCCOC(CO)Cn1cnc2c(=O)[nH]c(N)nc21</smiles><smiles>Nc1nc2c(ncn2COC(CO)CO)c(=O)[nH]1</smiles><smiles>Nc1ncnc2c1ncn2C1CCC(O)C1</smiles><smiles></smiles>

ZIDOVUDINE<smiles></smiles>

ESTAVUDINE<smiles></smiles>

EMTRICITABINE<smiles></smiles>

LAMIVUDINE<smiles></smiles>

ZALCITABINE

FIGURE 6 - Structures of bioprecursor-type antiviral prodrugs (ganciclovir and penciclovir) and antiretrovirals (zidovudine, estavudine, didanosine, emtricitabine, lamivudine, zalcitibine).

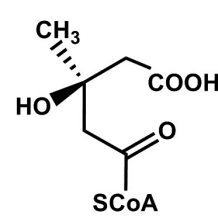

HMG-CoA

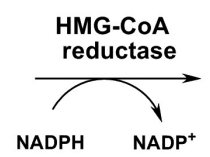

NADPH NADP $^{+}$

$$
\text { L }
$$

INTERMEDIATE

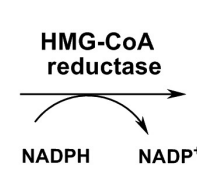

NADPH NADP $^{+}$

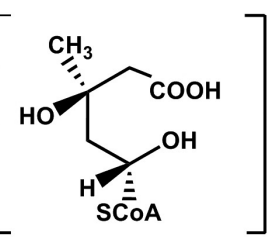

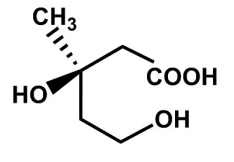

MEVALONIC ACID 30 STEPS

CHOLESTEROL

FIGURE 7 - The cholesterol biosynthetic pathway of HMGCo-A (hydroxy-methylglutaryl-Coenzyme A). 
presents hydroxy-methylglutaryl-Coenzyme A(HMGCoA) as a natural substrate. Upon acting on this substrate, HMGCo-A reductase converts it into mevalonic acid, one of the precursors of cholesterol synthesis (Mauro, 1993; Viegas-Junior et al., 2006).

The first statin to be isolated was mevastatin (Figure 8), a substance extracted from the fungus Penicillium sp. Researchers in Sankyo (Japan) noted the similarity of the active metabolite of mevastatin to the natural substrate of the cholesterol biosynthetic pathway. The effectiveness of this metabolite can be explained by the structural similarity to the precursor of cholesterol, as indicated in Figure 8.

Accordingly, mevastatin needs to be biotransformed into its active form (acyclic derivative) to become active. Consequently, this compound is a bioprecursor, since lactone hydrolysis is required (function $\gamma$-lactone$\beta$-hydroxylate) for its hypocholesterolemic function. The statins on the market, for example lovastatin and sinvastatin (Figure 9), which present the $\gamma$-lactone- $\beta$-hydroxylate function, are also bioprecursors. After being absorbed by

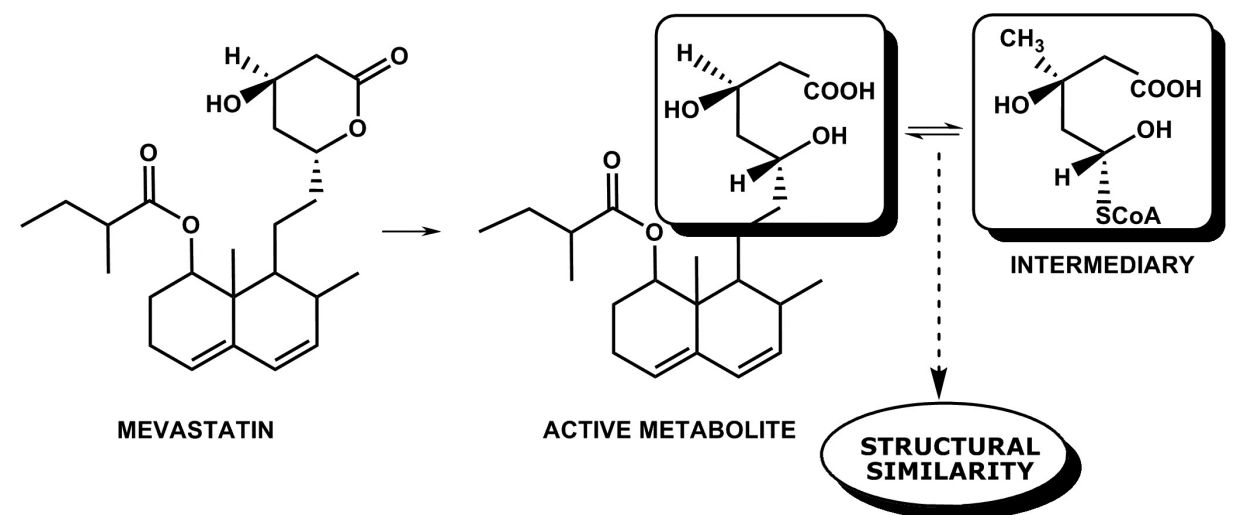

FIGURE 8 - The structure of mevastatin, of its active metabolite and the similarity to the HMG-CoA reductase substrate (intermediary).
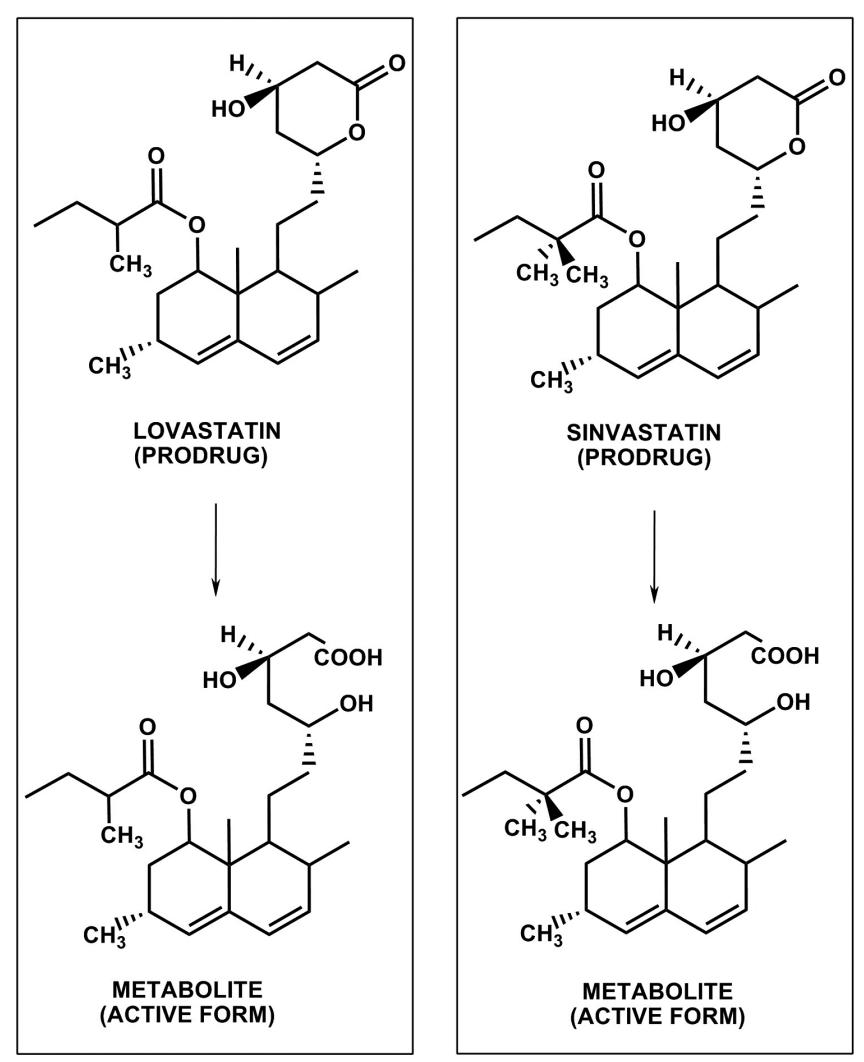<smiles>CCC(C)C(=O)OC1C[C@@H](O)C=C2C=CC(C)C(CC[C@H](O)C[C@H](O)CC(=O)O)C21C</smiles><smiles>CC(C)c1c(C(=O)Nc2ccccc2)c(-c2ccccc2)c(-c2ccc(F)cc2)n1/C=C/[C@H](O)C[C@H](O)CC(=O)O</smiles>

FIGURE 9 - Statins used in therapeutics.<smiles>CC(C)n1c(/C=C/[C@H](O)C[C@H](O)CC(=O)O)c(-c2ccc(F)cc2)c2ccccc21</smiles><smiles>CC(C)c1nc(N(C)S(C)(=O)=O)nc(-c2ccc(F)cc2)c1/C=C/[C@H](O)C[C@H](O)CC(=O)O</smiles> 
the intestine, lovastatin and sinvastatin are hydrolized and quickly converted into open hydroxy acids, which in turn correspond to the active metabolite (Roche, 2005).

On the other hand, pravastatin was the first statin to present an open lactone function and therefore it is not classified as a bioprecursor. For the same reason, fluvastatin, atorvastatin and rosuvastatin are also not considered bioprecursors (Campo, Carvalho, 2007; Viegas-Junior et al., 2006).

Lovastatin was approved for clinical use in 1987 and after its introduction, other statins were launched on the market and since then these compounds have also been ranked as "blockbuster" drugs. Currently, it is estimated that the world pharmaceutical market generates about 700 billion dollars a year, with the statin trade alone accounting for more than 15 billion dollars of this total (IMS, 2009; Viegas-Junior et al., 2006). This observation is an indication of the importance of latentiation of drugs in the world pharmaceutical market.

\section{Antiparkinsonian Agents}

A classic example of a bioprecursor prodrug is levodopa. This drug corresponds to the immediate dopamine precursor, although contrary to the latter, it is able to cross the blood-brain barrier. Levodopa has been used to treat Parkinson's disease, a condition caused by deficiency in dopamine, which cannot be employed due to insufficient lipophilicity to cross the blood-brain barrier. However, levodopa is an even more polar structure compared to dopamine. Its amino acid characteristic enables it to use transporters of neutral amino acids (LAT1) present in the blood-brain barrier and accordingly, it can cross the cellular membrane. Subsequently, it undergoes decarboxylation through the action of the aromatic L-amino acid decarboxylase, thus releasing dopamine (Figure 10) (Stefano et al., 2008; Bravo, Nassif, 2006).

\section{Antiulcerous agents}

The gastric $\mathrm{H}^{+} / \mathrm{K}^{+}$ATPase pump inhibitors, also called proton pump inhibitors, consist of a group of drugs widely employed in the treatment of gastric ulcers. The enzyme is responsible for the production of acid in the stomach and is located in the apical membranes of the pa- rietal cells. Over the last decade, these drugs have largely replaced $\mathrm{H}_{2}$ antihistamines, such as cimetidine, ranitidine and famotidine. The lowering of enzymatic activity leads to a reduction in the concentration of hydrogen ions $\left(\mathrm{H}^{+}\right)$in the stomach, thus increasing the stomach's $\mathrm{pH}$ (Lindberg et al., 1986; Roche, 2006).

The main inhibitors used in therapy in Brazil are omeprazole and its pure enantiomer, esomeprazole ( $\boldsymbol{S}$ omeprazole), along with lansoprazole, pantoprazole and rabeprazole (Figure 11) (Carneiro França, 2008; Robinson, 2004).

All of these drugs are administered in their inactive form, becoming active under acidic conditions of the canaliculi of the gastric mucosa, as shown in Figure 12 (Lindeberg et al., 1986). All members of this class are therefore considered to be bioprecursors (Barradell et al., 1992; Shin et al., 2004).

\section{Antineoplasic Agents}

Cyclophosphamide is a synthetic bioprecursor antineoplasic drug, belonging to the alkylating agents class of the nitrogen mustard group, that bonds covalently to DNA. This drug is inactive when tested in vitro on human lymphocyte cultures or on human neoplastic cells. However, in vivo, when converted to its active form by microsomal cells in the liver, it interferes with the growth of susceptible neoplastic tumors.

The biological function of cyclophosphamide, as well as the other members of the nitrogen mustard group, is based on the presence of the bis-(2-chloroethyl) group. Cyclophosphamide is hydroxylated in the liver by $\mathrm{CYP} 450_{2 \mathrm{~B}}$, and converted into 4-hydroxy-cyclophosphamide (Figure 13). This dependency on bioactivation by the CYP450 system is an advantage over other compounds of the nitrogen mustard group (Cohen, Jao, 1970). These are chemically unstable to varying degrees, with some reacting almost totally in the organism a few minutes after being administered, which can lead to high rates of toxicity (Griskevicius et al., 2003).

The 4-hydroxy-cyclophosphamide is found in dynamic equilibrium with its acyclic tautomer, aldofosfamide. It can undergo two pathways of biotransformation, one enzymatic and the other non-enzymatic. Through the enzymatic pathway, it can be oxidized to aldehyde in the liver

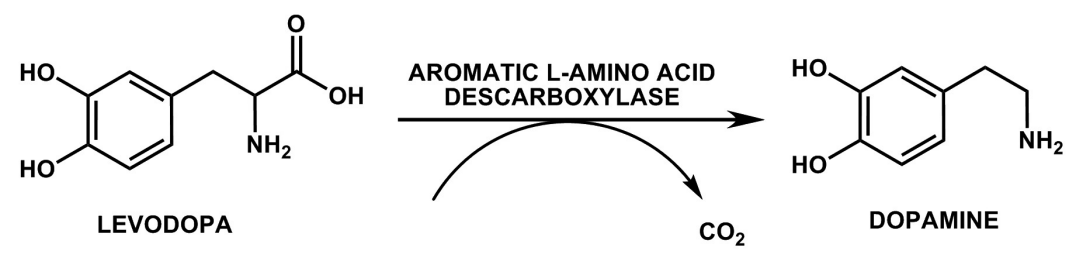

FIGURE 10 - Metabolic pathway for dopamine formation. 
<smiles>COc1ccc2nc(S(=O)Cc3ncc(C)c(OC)c3C)[nH]c2c1</smiles><smiles>COc1ccnc(CS(=O)c2nc3ccc(OC(F)F)cc3[nH]2)c1OC</smiles><smiles>CCOCCOC(C)=O</smiles><smiles>CCCOc1ccnc(CS(=O)c2nc3ccccc3[nH]2)c1C</smiles><smiles>COc1ccc2nc(S(=O)Cc3ncc(C)c(OC)c3C)[nH]c2c1</smiles>

FIGURE 11 - The main gastric $\mathrm{H}^{+} / \mathrm{K}^{+}$ATPase inhibitors.<smiles>COc1ccc2nc(S(=O)Cc3ncc(C)c(OC)c3C)[nH]c2c1</smiles><smiles>COc1ccc2nc(-[n+]3cc(C)c(OC)c(C)c3CSO)[nH]c2c1</smiles><smiles>COc1ccc2nc(-[n+]3cc(C)c(OC[14c]4ccccc4)c(C)c3CSSCC(C)C)[nH]c2c1</smiles><smiles>COc1ccc2nc3n(c2c1)SCc1c(C)c(OC)c(C)c[n+]1-3</smiles>

OMEPRAZOLE-ENZYME COMPLEX

FIGURE 12 - Omeprazole activation mechanism and sequential inhibition of gastric $\mathrm{H}^{+} / \mathrm{K}^{+}$ATPase.

or in the tumor and, perhaps by other enzymes, producing carboxy-phosphamide and 4-ceto-cyclophosphamide that have no significant biological activity. Through the nonenzymatic pathway, aldofosfamide undergoes spontaneous cleavage, producing fosforamide mustard and acrolein, the former being responsible for antitumoral effects, and the latter for haemorrhagic cystitis observed after using cyclophosphamide. The fosforamide mustard engages DNA in the tumor cells, resulting in the cross-bonding of the nucleic acid chains or binding to a nucleic acid or a protein. Such alterations severely damage the DNA molecule, leading to the demise of the cell (Lemke, Williams, 2008; Rooney et al., 2004; Santos et al., 2007).Currently, besides cyclophosphamide, a derivative of this drug, ifosfamide, 


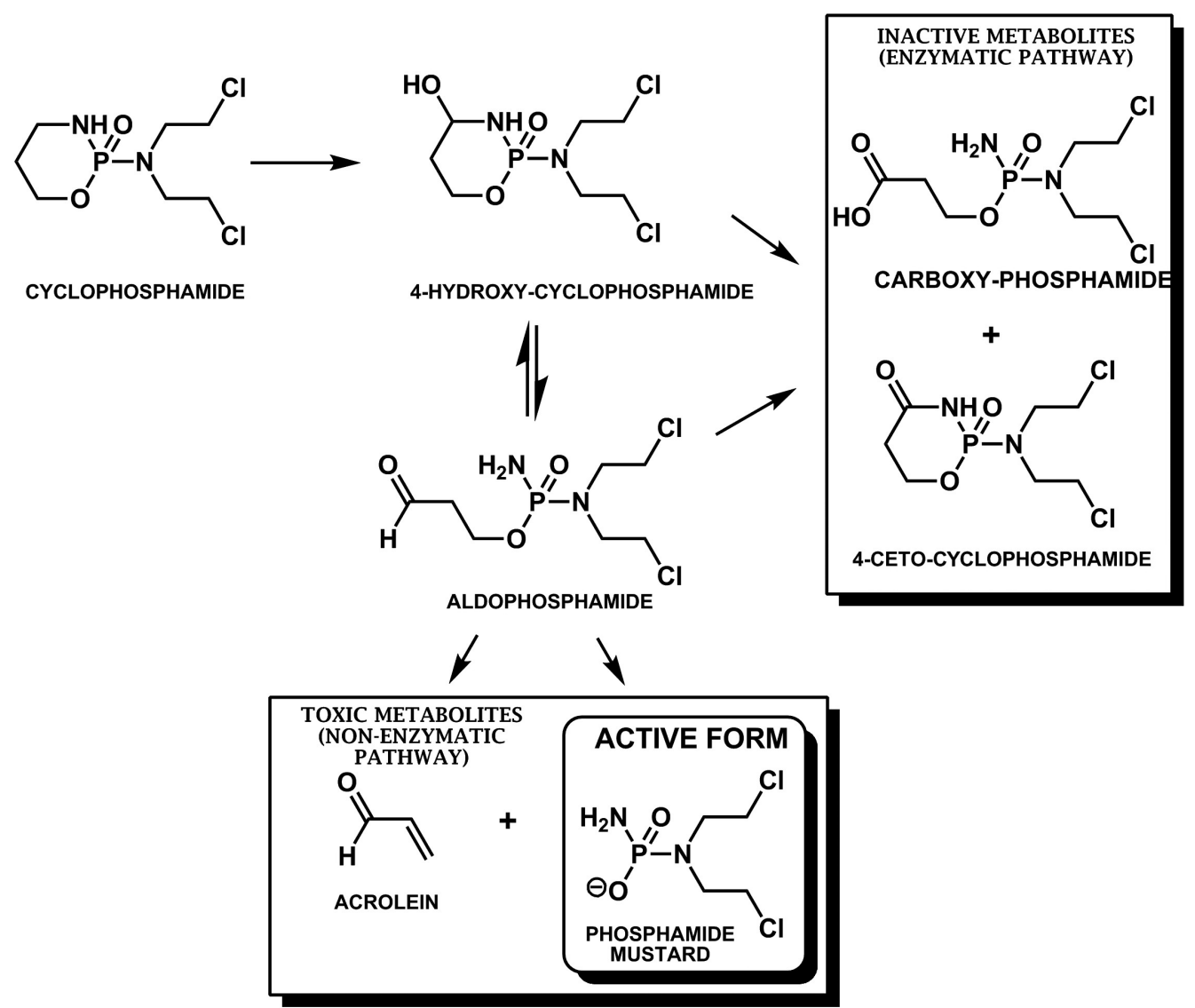

FIGURE 13 - Diagram of cyclophosphamide bioactivation.

is employed in anticancer chemotherapy treatment. This drug also requires bioactivation, and is thus another example of a bioprecursor prodrug (Lemke, Williams, 2008).

\section{Classic prodrugs}

Classic prodrugs are obtained from the binding of a matrix drug and an adequate transporter group through a covalent hydrolysable bond. The purpose of these prodrugs is to improve physical-chemical properties and consequently, overall therapeutic effectiveness, with a reduction in toxicity, prolonged action and an increase in bioavailability or selectivity. They are normally inactive and need to undergo chemical or enzymatic hydrolysis, thus releasing the active portion. Therefore, they abide by the classical definition of latentiation (Beaumont et al., 2003; Chung et al., 2005).

The main classic prodrugs available on the Brazilian market are listed below, divided according to the different therapeutic categories.

\section{Antivirals}

Valacyclovir (Carneiro França, 2008) is a classic prodrug of acyclovir (Figure 14) and is therefore active against the Herpes simplex (VHs) virus, types 1 and 2, and Varicella zoster (VVZ), Epstein Barr (VEB) virus and cytomegalovirus (CMV). This prodrug was obtained from the esterification reaction between acyclovir and the valine amino acid.

Valacyclovir was designed to increase the bioavailability of acyclovir. Peptide transporters represent attractive groups for the development of prodrugs. Prodrugs that have amino acids as transport groups present three- to ten-fold greater passage through the membrane than the original drug. Thus, the greater absorption of valacyclovir compared to acyclovir is due to the presence of the amino acid (valine) (Ettmayer et al., 2004; Thomsen et al., 2003; Thomsen et al., 2004; Vabeno et al., 2004). The presence of valine enables the passage of the drug through membranes by means of specific amino acid transporters (hPEPT 1 and 2) (Andersen et al., 2006; Steingrimsdottir et al., 2000; Steffansen et al., 2004; Sugawara et al., 2000). Upon absorption, orally ingested valacyclovir is converted into acyclovir by the action of esterases. The acyclovir, in turn, is affected by viral thymidine kinase, thus transforming into its active form, acyclovir monophosphate, and then 


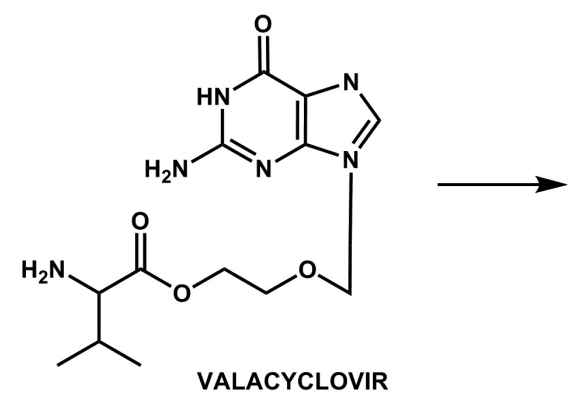<smiles>[R]OC(=O)OCOCn1cnc2c(=O)[nH]c(N)nc21</smiles>

FIGURE 14 - Reaction illustrating the release of acyclovir from its prodrug.

di and triphosphate, with 54\% absolute bioavailability, compared to the $12-20 \%$ of acyclovir. The fact that the bioavailability of oral valacyclovir is considerably greater than that obtained from oral acyclovir results in the need for smaller daily doses (Guo et al., 1999; Han, Amidon, 2000).

Fancyclovir (Carneiro França, 2008), the diacetate of pencyclovir, is classified as a classic prodrug (Figure 15), whose purpose is to increase bioavailability. Fancyclovir was acquired after the acetylation of the hydroxyl groups present in the "open sugar" of pencyclovir. This compound was developed to adjust the pharmacokinetic properties of pencyclovir, which has limited oral absorption (4\% oral bioavailability) which is increased to $75 \%$ with fancyclovir (Barreiro, Fraga, 2008; Simpson, Lyseng-Williamson, 2006). After absorption, fancyclovir is biotransformed by esterases, and pencyclovir is released which is subsequently affected by viral thymidine kinase, and is hence transformed into its active form, pencyclovir triphosphate.

Fosamprenavir is an antiretroviral drug belonging to the class of protease inhibitors. It inhibits this enzyme, preventing the breakdown of a polyprotein precursor into functional and structural proteins of HIV (Stella et al., 2007). Fosamprenavir is a prodrug of amprenavir (Figure 16).

Fosamprenavir is a calcium phosphate ester of amprenavir. This prodrug was designed to optimize the use of amprenavir by reducing the heavy dosage regimen, which in turn significantly reduces the quantity of pills to be taken compared to amprenavir, and accordingly, minimizing collateral effects. Therapy with amprenavir requires the ingestion of eight capsules daily to reach the total dosage of $1200 \mathrm{mg}$. In contrast, the use of its prodrug requires the administration of only two pills per day, containing a total of $1400 \mathrm{mg}$. Fosamprenavir is a more hydrosoluble derivative (10 times more soluble in water), compared to amprenavir, facilitating its formulation and absorption. Upon oral administration, fosamprenavir is quick and almost completely hydrolyzed in amprenavir and inorganic phosphate. The conversion of fosamprenavir into amprenavir, as well as its absorption, takes place in the intestinal epithelium. Fosamprenavir was licensed for the treatment of AIDS in 2004 (Chapman et al., 2004; Wire et al., 2006).

Tenofovir disoproxil is a prodrug derived from tenofovir, an analog of monophosphorylated nucleoside, which acts by inhibiting reverse transcriptase, an important HIV enzyme capable of promoting the transcription of viral RNA into viral DNA(Chapman et al., 2003; Gallant, Deresinski, 2003). The prodrug tenofovir disoproxil fumarate was designed as a solution to overcome the limited oral bioavailability of tenofovir. It is transformed into tenofovir upon absorption (Figure 17). The hydrolysis

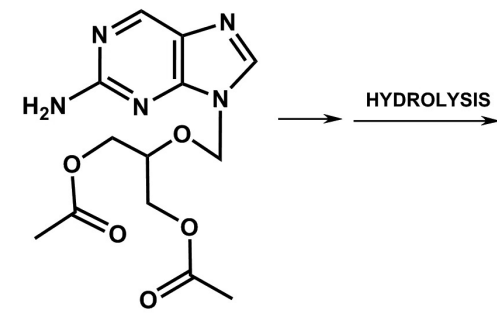

FANCYCLOVIR

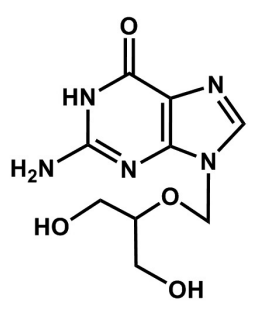

PENCYCLOVIR

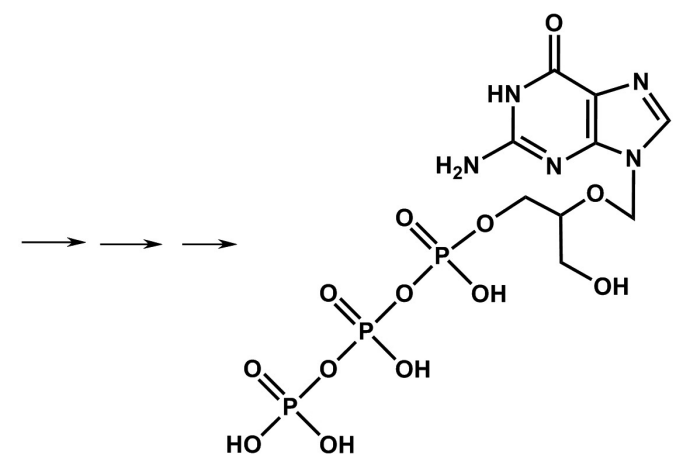

PENCYCLOVIR TRIPHOSPHATE

FIGURE 15 - The bioactivation pathway of fancyclovir. 


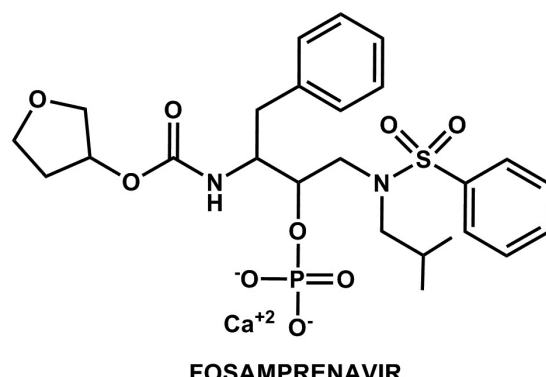<smiles>CCCCCCCCCCCCCC(O)C(Cc1ccccc1)NC(=O)OC1CCOC1</smiles>

FOSAMPRENAVIR

AMPRENAVIR

FIGURE 16 - Fosamprenavir structure (prodrug) and its conversion into amprenavir.

of tenofovir disoproxil fumarate, promoted by esterases, stechiometrically generates four types of molecules: isopropanol, carbon dioxide, formaldehyde and tenofovir (Larsen et al., 2004).

Oseltamivir is an orally administered prodrug of proven efficacy in the treatment of infections caused by the Influenza A and B viruses. This prodrug is converted into carboxylate of oseltamivir (GS4071), its active form, by hepatic esterases (Figure 18). The active metabolite is a powerful and selective inhibitor of the neuraminidase enzyme, a glycoprotein present on the surface of the virus, essential for the release of viral particles recently formed from infected cells and for the later expansion of the infecting virus in the organism. The prodrug was designed to improve the bioavailability of its precursor, GS4071. Considering that carboxylate is a very hydrosoluble che- mical entity, the masking of this group was promoted by the formation of an ethyl ester. Accordingly, oseltamivir presents greater lipophilicity and, consequently, greater bioavailability (Fatima et al., 2005; Finley et al., 1999; Hayden et al., 1999; He et al., 1999).

\section{Cardiovascular agents}

The angiotensin-converting enzyme inhibitors represent a fairly significant class of cardiovascular drugs. The introduction of this family of antihypertensive agents arose from the experimental work carried out by Sérgio Ferreira involving venom from the Bothrops jararaca snake (Ferreira, 1965). A peptide was identified in this venom that, when administered intravenously, was capable of preventing the conversion of angiotensin I into angiotensin II, through the inhibition of the angiotensin-converting en-<smiles>CCOCCOC(=O)OCOP(=O)(CO[C@@H](C)Cn1cnc2c(N)ncnc21)OCOC(=O)OC(C)C</smiles>

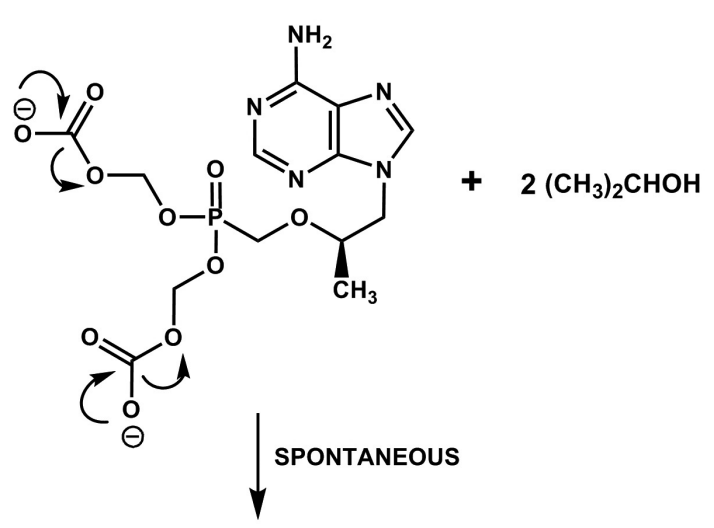

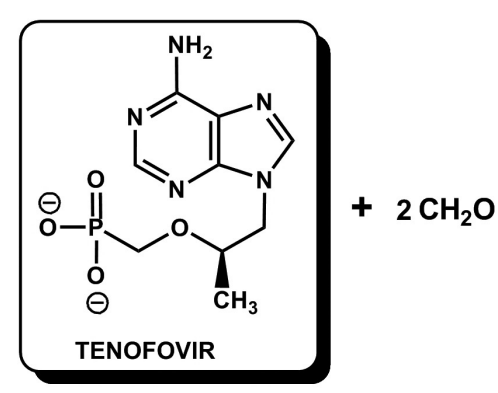

SPONTANEOUS

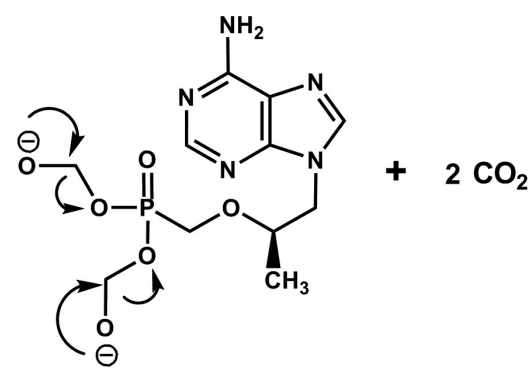

FIGURE 17 - Chemical and enzymatic hydrolysis of tenofovir disoproxil fumarate into its active component, tenofovir. 


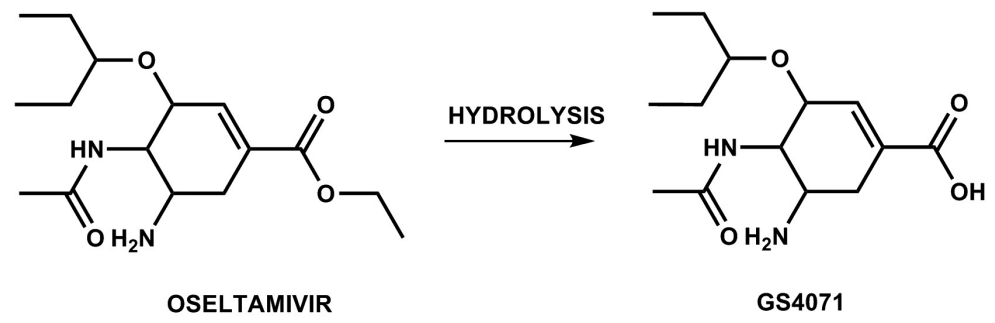

FIGURE 18 - The activation of olsetamivir into the active metabolite GS4071.

zyme (ACE). Based on the recognition that ACE inhibition results in hypotensive activity, a series of powerful ACE inhibitors was developed, which are active upon oral administration (Wermuth, 2006). Captopril, marketed under several pharmaceutical brandnames (Carneiro França, 2008) (Figure 19), was the first ACE inhibiting antihypertensive agent and is an example of a drug developed from rational drug design, supported by contributions from Brazilian researchers. Captopril presents satisfactory bioavailability, when administered orally. However, it is one of the ACE inhibiting drugs with the lowest half-lives, compared to others from the same class, for example, enalapril, benazepril, quinapril, ramipril and fosinopril (Friedman, Amidon, 1989; Dhareshwar et al., 2007), all classified as prodrugs with greater advantages in terms of half-life and improved bioavailability (Figure 19).

Esterification of the ester group or etherification of the phosphate group leads not only to an increase in liposolubility, but also minimizes the biotransformation that rapidly takes place in the carboxylic-free group (Beaumont et al., 2003). Thus, as intended, the bioavailability and the half-life of the prototype drugs are altered.

\section{Antibiotics}

The antibiotics class includes a very wide range of prodrugs available for use in therapy, whether to increase bioavailability, reduce toxicity or even to solve organoleptic and pharma-technical issues (Chung, Ferreira, 1998).

Ampicillin is currently a fairly widely used antibiotic due to its broad spectrum bactericidal activity and reduced toxicity. However, its bioavailability, when ingested orally, is only $30 \%$ to $50 \%$, due to its low absorption (Carneiro França, 2008). Thus, there is an interest in ampicillin prodrugs with more lipophilic transporters, and a subsequent increase in lipophilicity. Bacampicillin (Figure 20) is an example of a classic ampicillin prodrug, with greater bioavailability than the penicillin it is derived from. With bioavailability greater than $95 \%$, bacampicillin is administered in an average oral dose of $400 \mathrm{mg}$ and thus attains high plasmatic levels, $7 \mu \mathrm{g} / \mathrm{ml}$, which is equivalent to 1000 $\mathrm{mg}$ of ampicillin. This pharmacokinetic characteristic provides rapid and elevated plasmatic concentrations, two or three times greater than those attained from the same doses of ampicillin. Its plasmatic half-life is approximately 60 minutes in individuals with normal renal function. Furthermore, its binding with plasmatic proteins is very low (18\%), maintaining a high concentration of free and therapeutically active ampicillin (Bergan, 1978; Bodin et al., 1975; Sjövall et al., 1978).

It is important to observe that the transporter bonded to position 2 of the thiazolidine ring is a double ester. This characteristic means greater access of the enzyme to the ester further away from the ring, thus preventing any steric hindrance that could interfere with the release of the drug. The esterases cleave the ester bond and a spontaneous rearrangement releases ampicillin and aldehyde, as illustrated in Figure 20.

The cephalosporin class of antibiotics also includes several prodrugs. Those of third and fourth generations, in particular, are fairly hydrophilic drugs that include aminotiazol and methoxamine groups in their structure, which are responsible for their broad spectrum bactericidal activity and resistance to beta-lactamases, respectively. Despite these characteristics, the high hydrosolubility of these more recent generation of cephalosporins impairs gastro-intestinal absorption, making oral administration unfeasible (Patrick, 2005). This difficulty led to the design of new chemical entities with, simultaneously, oral absorption, broad spectrum bactericidal activity and resistance to beta-lactamases. Accordingly, new orally administered cephalosporin prodrugs have arisen based on dual-esters, such as cefuroxime axetil, cefpodoxime proxetil and cefetamet pivoxil (Fuchs, 2007; Stella et al., 2007). As with bacampicillin, these prodrugs, being more lipophilic, are administered orally and feature greater bioavailability. After absorption, they initially undergo enzymatic hydrolysis, followed by a chemical rearrangement due to the electronic characteristics of the intermediary formed, thus releasing cephalosporin (Figures 21 and 22) (Ehrnebo et al., 1979; Perry, Brogden, 1996).

Chloramphenicol is an antibiotic that was isolated by Burkholde for the first time in 1947 from Streptomyces 


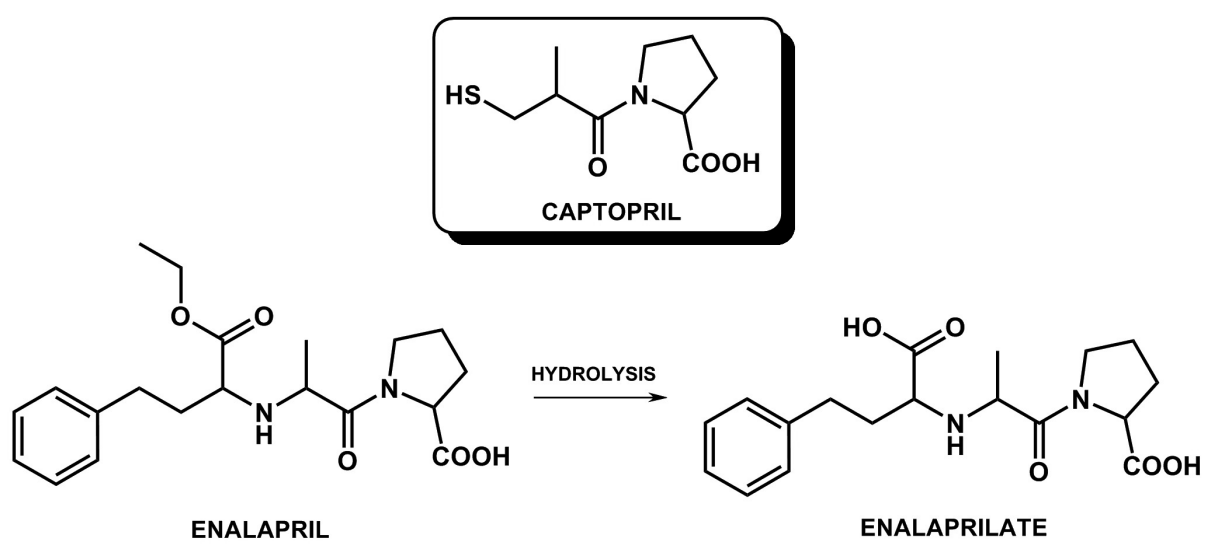<smiles>CCOC(=O)C(CCc1ccccc1)NC1CCc2ccccc2N(C(=O)O)C1=O</smiles>

BENAZEPRIL<smiles>CCOC(=O)C(CCc1ccccc1)NC(C)C(=O)N1CCc2ccccc2C1C(=O)O</smiles>

QUINAPRIL<smiles>[R10]Nc1ccccc1</smiles>

RAMIPRIL<smiles>CCC(=O)OC(OP(=O)(CCCCc1ccccc1)CC(=O)N1CC(C2CCCCC2)CC1C(=O)O)C(C)C</smiles>

FOSINOPRIL<smiles>O=C(O)C(CCc1ccccc1)NC1CCc2ccccc2N(C(=O)O)C1=O</smiles>

BENAZEPRILATE<smiles>CC(NC(CCc1ccccc1)C(=O)O)C(=O)N1CCc2ccccc2C1C(=O)O</smiles>

QUINAPRILATE<smiles>CC(NC(CCc1ccccc1)C(=O)O)C(=O)N1CC2CCCC2C1C(=O)O</smiles>

RAMIPRILATE<smiles>O=C(O)C1CC(C2CCCCC2)CN1C(=O)CP(=O)(O)CCCCc1ccccc1</smiles>

FOSINOPRILATE

FIGURE 19 - Angiotensin-converting enzyme (ACE) inhibiting prodrugs and their respective hydrolyses to their active forms

venezuelae. This compound was the first antibiotic effective against a wide variety of microorganisms to be used particularly in the treatment of serious infections such as typhoid fever and other forms of salmonellosis, Haemophilus Influenza infections, especially of the meninges, as well as other infections of the nervous system and respiratory tract (Carneiro França, 2008). However, it is associated with severe toxic side effects such as bone marrow depression, especially fatal aplastic anemia (Powell, Nahata, 1982). 

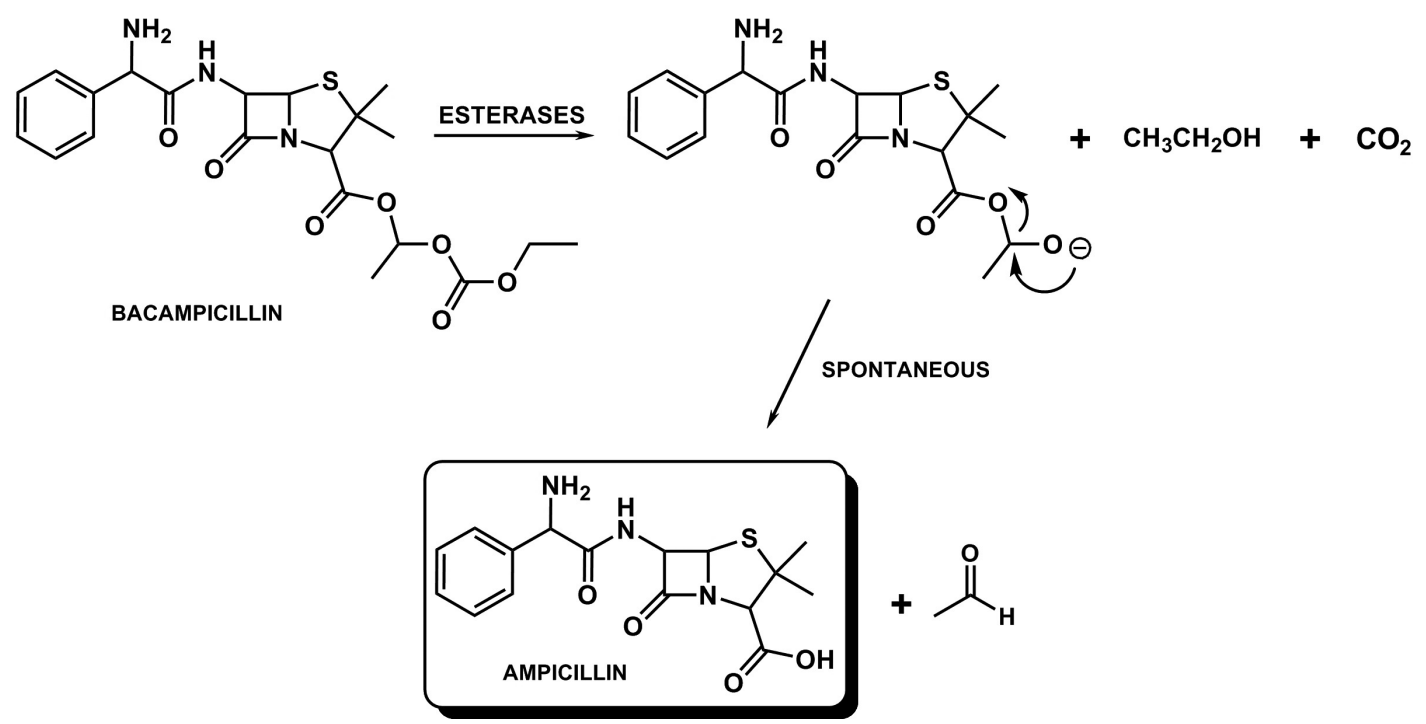

FIGURE 20 - Bacampicillin structure and its conversion into ampicillin.<smiles>CO/N=C(\C(=O)NC1C(=O)N2C(C(=O)OC(C)OC(C)=O)=C(COC(N)=O)CSC12)c1ccco1</smiles>

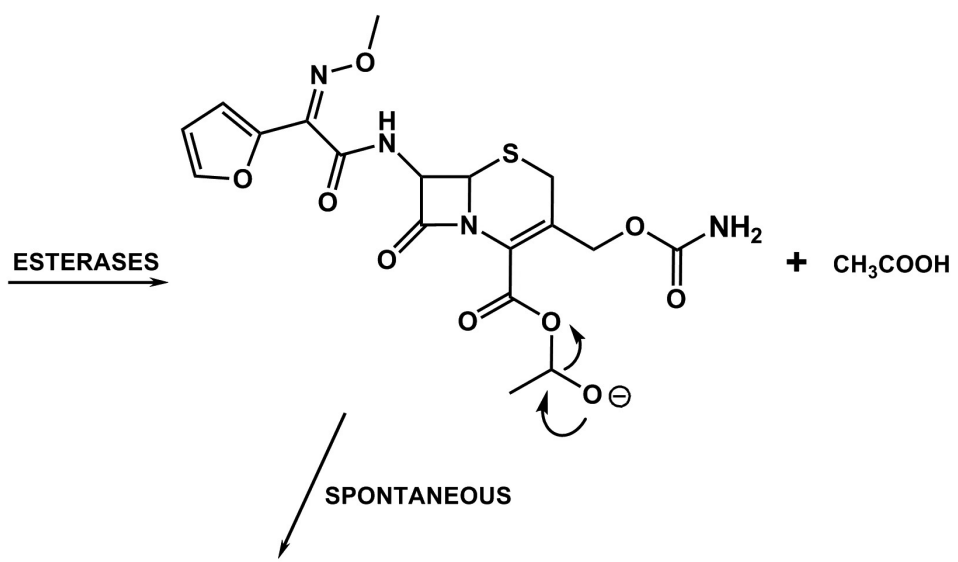

CEFUROXIME AXETIL

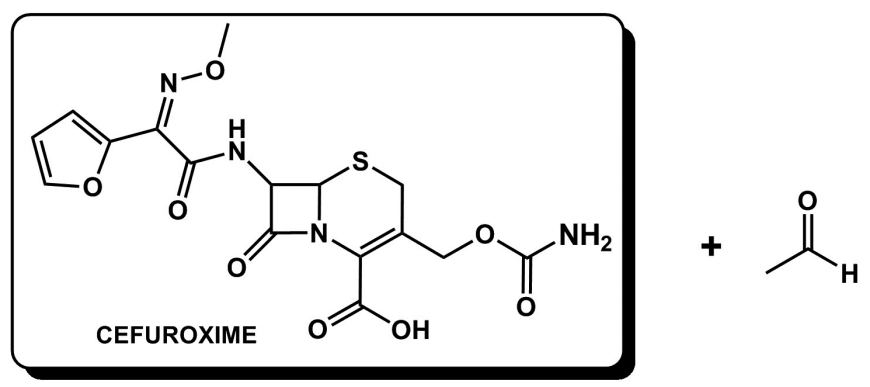

FIGURE 21 - Cefuroxime axetil structure and its conversion into cefuroxime.

With the appearance of safer agents, chloramphenicol is frequently considered to be an antibiotic of purely historical interest. However, it is still useful in some situations, such as in seriously ill individuals for whom safer alternatives are less effective, or when such alternatives are not available. This drug has a bitter taste, which is difficult to mask in orally administered solutions. Researchers discovered that the drug became flavorless when transformed in palmitic ester, due to the reduction of hydrosolubility
(Figure 23). Chloramphenicol palmitate is a prodrug of cloramphenicol, obtained from the sterification reaction between the drug and palmitic acid. It is therefore inactive, and for it to become active, it undergoes hydrolysis of the ester bond through the action of pancreatic lipases in the duodenum ${ }^{54}$. The acquired prodrug is a lipophilic compound, which means it can be marketed as an oral suspension (Bechelli, 2003; Carneiro França, 2008).

With the aim of acquiring a hydrosoluble pharma- 

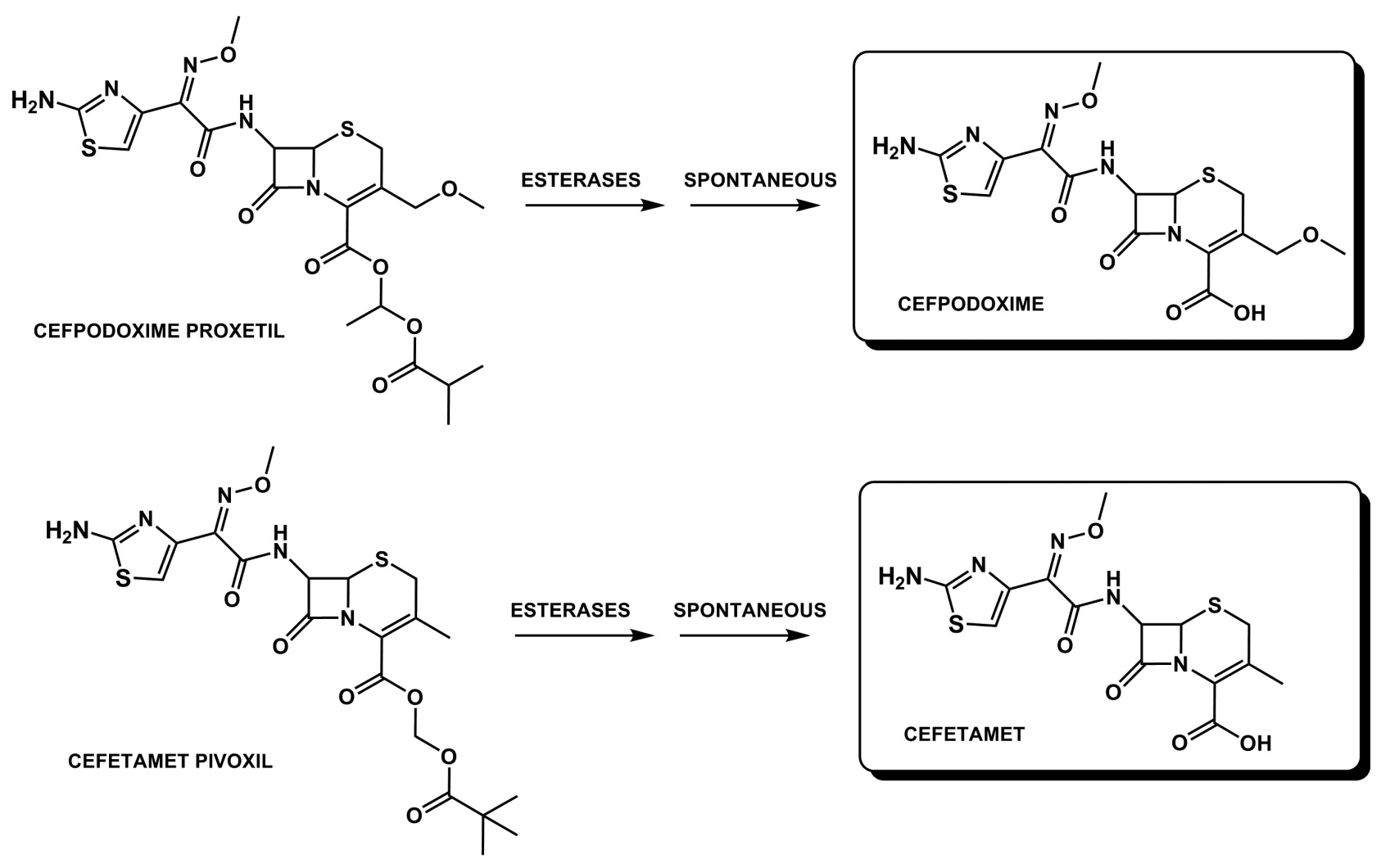

FIGURE 22 - Cefpodoxime proxetil and cefetamet pivoxil structures being bioactivated into cefpodoxime and cefetamet, respectively.

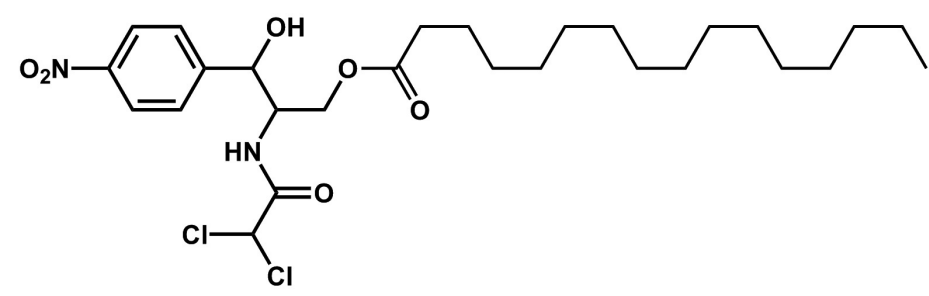

CHLORAMPHENICOL PALMITATE

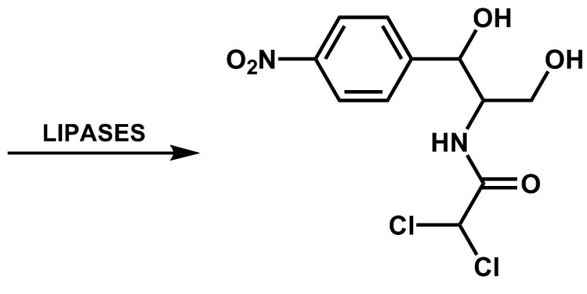

CHLORAMPHENICOL

FIGURE 23 - Enzymatic conversion of the chloramphenicol palmitate into chloramphenicol, its active form.

ceutical form for ophthalmic application, chloramphenicol has also been transformed into succinic hemiester (Figure 24), which, through hydrolysis, releases the antibiotic locally (Carneiro França, 2008).

Erythromycin (Figure 25) is a macrolide antibiotic, structurally characterized by the presence of a 14-atom lactone, to which two sugars are bonded. One of these sugars features an amino group, giving the drug the characteristic of a weak base that enables the formation of salts with organic acids (Lemke, Williams, 2008). It is a drug that is effective against a wide variety of microorganisms. However, its bitter taste and instability in an acidic medium prevented its therapeutic use. In an attempt to solve these limitations, its derivatives, erythromycin stearate and erythromycin esto- late, are used for therapy in Brazil (Carneiro França, 2008; Tavares, 2001). Erythromycin stearate is a salt capable of reducing the bitterness and, especially, increasing stability in an acidic medium. The lauryl sulfate salt of propionyl erythromycin ester, more commonly known as erythromycin estolate, is the prodrug available in Brazil (Carneiro França, 2008; Tavares, 2001). This prodrug is obtained from the sterification reaction between the hydroxyl group of amino sugar present in erythromycin and propionic acid carboxyl group, which acts as a transporter group. Sterification reduces the bitterness of erythromycin and increases its oral absorption, releasing free erythromycin into the bloodstream or muscle tissue after the action of esterases. Data from literature indicates that erythromycin estolate is 


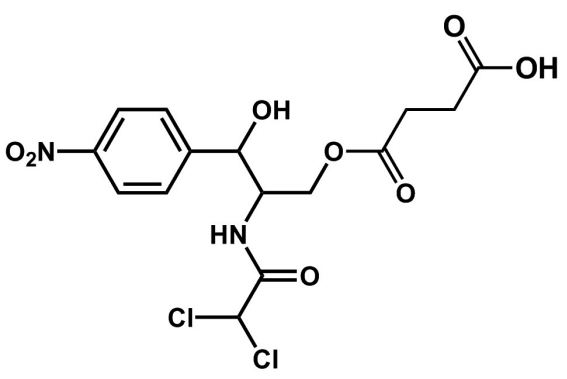

CHLORAMPHENICOL SUCCINATE

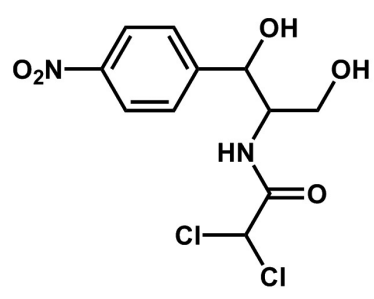

CHLORAMPHENICOL

FIGURE 24 - Bioactivation of chloramphenicol succinate.

capable of producing more elevated and prolonged serum levels than other salts due to the greater absorption rate of esters (Lemke, Williams, 2008; Tavares, 2001). Figure 25 illustrates the structures of erythromycin, erythromycin stearate and erythromycin estolate.

\section{Antipsychotics}

Antipsychotics are drugs used for the treatment of schizophrenia. In some circumstances, orally administered medicine regimens are not suitable for schizophrenic patients and the administration of long-acting prodrugs by intramuscular injection is recommended. This is the safest means of maintaining clinical stability and preventing relapses. In Table 1, several long-acting antipsychotics are listed. For instance, fluphenazine enanthate, haloperidol decanoate, zuclopenthixol decanoate and pipothiazine palmitate are available on the Brazilian market (Carneiro França, 2008). All are administered by intramuscular injection and obtained through sterification reaction between the drugs and long-chain carboxylic acids, which confer a high rate of liposolubility on the resulting derivatives (Bechelli, 2003).

Fluphenazine decanoate (piperazine phenothiazine) and haloperidol decanoate (butyrophenone) are prodrugs administered in an oil-based depot injection, where the agent is stored in the adipose tissue and then gradually released into the organism over a long period of time. After deep intramuscular injection, fluphenazine decanoate and haloperidol decanoate spread slowly and are hydrolyzed into their active forms fluphenazine and haloperidol, respectively, which then cross the blood-brain barrier (Figure 26). It is possible to obtain a stable serum concentration from the drugs for nearly four weeks after an initial peak, and half-life is in the range of 2.5 to 16 weeks (Beresford, Ward, 1987; Jann et al., 1985).

\section{Steroid hormones}

One of the strategies for extending the period of action is to design prodrugs with increased lipophilicity, thus obtaining depot forms whose drugs are gradually release into the organism (Batres et al., 1956). This strategy can be observed in the development of sexual hormones with long-acting release during contraceptive therapy, hormonal replacement therapy or pregnancy (Petrow, 1970; Ghiselli, Jardim, 2007). The use of prodrug steroid hormones in therapy may also be applied to compounds that can be administered orally, thus increasing the absorption of the hormones. This design involves the binding of the hormone to a transporter group, generally masking a hydrophilic functional group, through an ester bond which increases lipophilicity and leads to derivatives for oral or parenteral administration. The extension of the period of action of these steroid hormones derived from parenterally

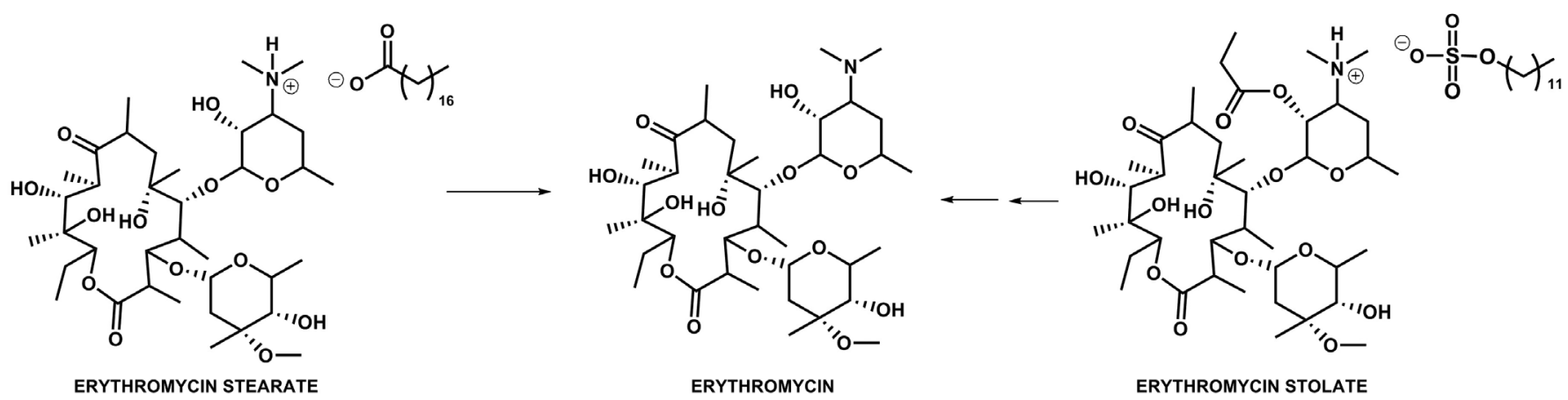

FIGURE 25 - Conversion of erythromycin stearate and erythromycin estolate into erythromycin. 
TABLE I - Long-acting antipsychotics

\begin{tabular}{lc}
\hline PRODRUGS & ADMINISTRATION INTERVAL (WEEKS) \\
\hline BROMPERIDOL (DECANOATE) & 4 \\
CLOPENTIXOL (DECANOATE) & 3 to 4 \\
FLUPHENAZINE (DECANOATE) & 2 to 3 \\
FLUPHENAZINE (ENANTHATE) & 2 \\
HALOPERIDOL (DECANOATE) & 4 \\
PERPHENAZINE (DECANOATE) & 3 to 4 \\
PERPHENAZINE (ENANTHATE) & 2 \\
PIPOTHIAZINE (PALMITATE) & 2 \\
PIPOTHIAZINE (UNDECYLENATE) & 4 \\
ZUCLOPENTIXOL (DECANOATE) & 2 to 4 \\
\hline
\end{tabular}

administered esters can be explained by the slow absorption from the site of administration or by the resistance to biotransformation (Biagi et al., 1975).

A practical and long-acting form of contraception is the use of injectable progesterone prodrugs, providing 2-4 months of contraception. There are also monthly injections, which are combinations of estrogen and progesterone prodrugs, administered in intramuscular injections once a month (Araújo-Junior, Athanazio, 2007). The structures of steroid hormone prodrugs, as well as their release to active form, are illustrated in Figure 27. The main compounds include (Carneiro França, 2008): medroxyprogesterone acetate, hydroxyprogesterone caproate, algestone acetophenide (long-acting progestogens), estradiol valerate and estradiol enanthate (estrogenic prodrugs) (Aguilar et al., 1997; Mishell, 1996; Pasqualini, 1996).

\section{Anti-asthmatic agents}

Bambuterol is a prodrug of long-acting terbutaline, with an effective duration of 24 hours, thus able to be administered once a day. Bambuterol features catecholic hydroxyls (susceptible to pre-systemic metabolism). The fact that this type of bond is relatively resistant to hydrolysis explains the longer action of bambuterol. Terbutaline is an adrenergic agonist, which predominantly stimulates the beta- 2 receptors, thus producing relaxation of the smooth muscle of the bronchus. After being absorbed, bambuterol undergoes a slow biotransformation, as indicated in

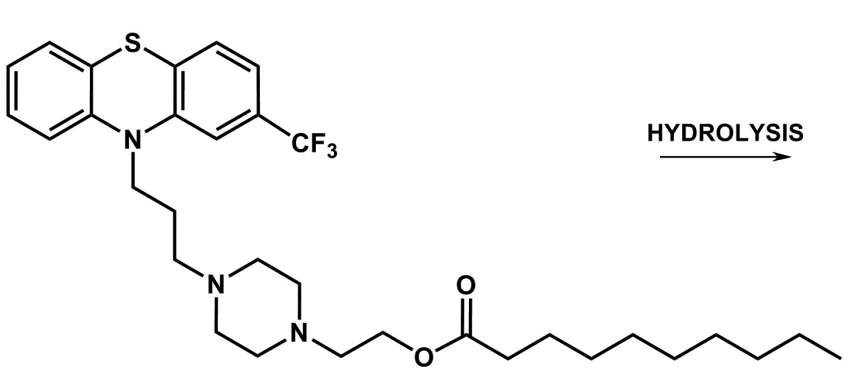

FLUPHENAZINE DECANOATE

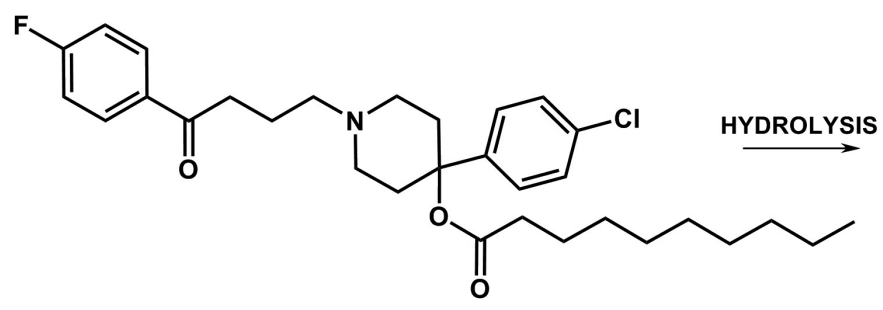

HALOPERIDOL DECANOATE<smiles>OCCN1CCN(CCCN2c3ccccc3Sc3ccc(C(F)(F)F)cc32)CC1</smiles>

FLUPHENZINE<smiles>O=C(CCCN1CCC(O)(c2ccc(Cl)cc2)CC1)c1ccc(F)cc1</smiles>

HALOPERIDOL

FIGURE 26 - Release of haloperidol and fluphenazine from their respective prodrugs. 
<smiles>CC(=O)OC1(C(C)=O)CCC2C3CC(C)C4=CC(=O)CCC4(C)C3CCC21C</smiles>

MEDROXYPROGESTERONE ACETATE<smiles>CCCCCC(=O)OC1(C(C)=O)CCC2C3CCC4=CC(=O)CCC4(C)C3CCC21C</smiles>

HYDROXYPROGESTERONE CAPROATE<smiles>CC(=O)C1(O)CCC2C3CC(C)C4=CC(=O)CCC4(C)C3CCC21C</smiles>

MEDROXYPROGESTERONE

HYDROLYSIS<smiles>CC(=O)C1(O)CCC2C3CCC4=CC(=O)CCC4(C)C3CCC21C</smiles>

HYDROXYPROGESTERONE<smiles>CC(=O)C12OC(C)(c3ccccc3)OC1CC1C3CCC4=CC(=O)CCC4(C)C3CCC12C</smiles>

ALGESTONE ACETOPHENIDE

HYDROLYSIS

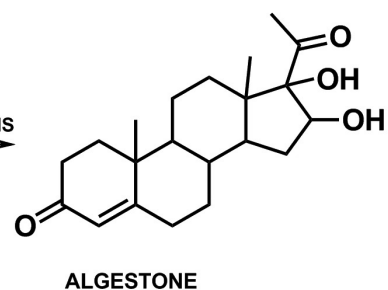<smiles>CCCCCCC(=O)OC1CCC2C3CCc4cc(O)ccc4C3CCC12C</smiles>

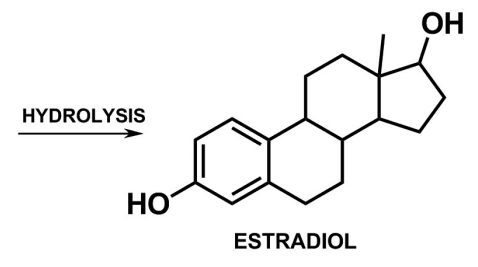

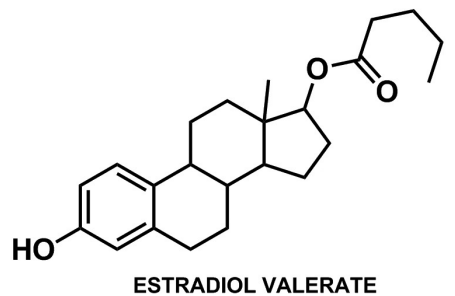

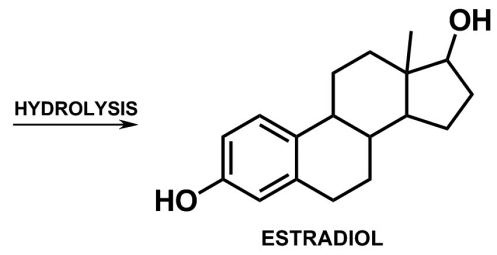

FIGURE 27 - The main sexual hormones available on the market and their bioactivation.

Figure 28, through hydrolytic and oxidation metabolic conversion, in order to form terbutaline. The maximum plasmatic concentration $\left(\mathrm{C}_{\max }\right)$ of the active metabolite (terbutaline) is reached in approximately 2-6 hours and it lasts at least 24 hours (Rautio et al., 2008; Rosenborg et al., 2001; Testa, 2004; Tunek, Svensson, 1988).

\section{Antiglaucoma agents}

Dipivefrin, derived from epinephrin is recommen- ded for the treatment of ocular hypertension in openangle chronic glaucoma, and it functions by reducing the production of aqueous humor (Carneiro França, 2008). Dipivefrin is a prodrug of epinephrin obtained from the sterification of the catecholic hydroxyl groups present in epinephrin with pivalic acid. This sterification leads to an increase in lipophilicity and as a consequence, this prodrug is capable of permeating the corneal extract 17 times faster than epinephrin. After absorption, hydrolysis of the esters 


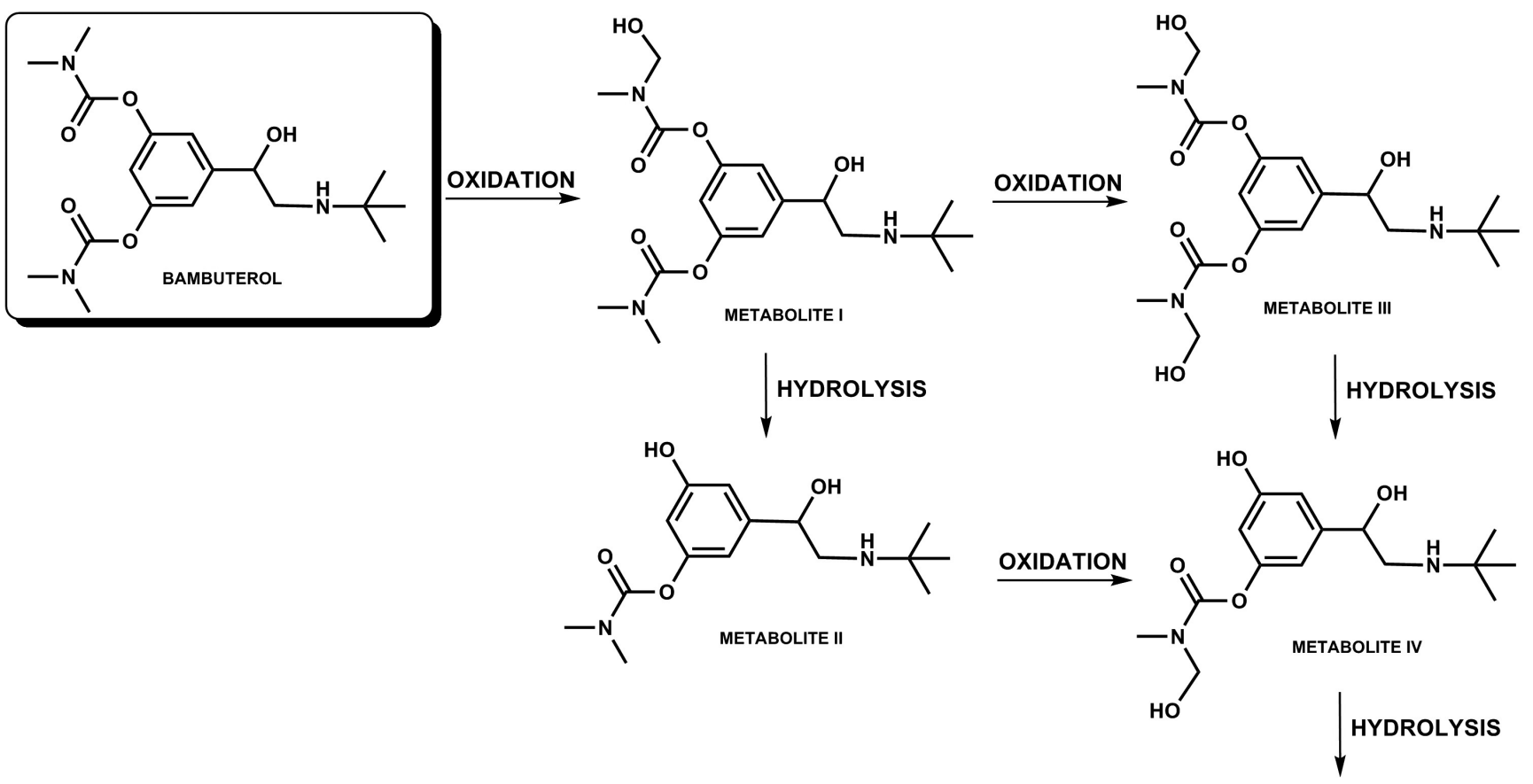

FIGURE 28 - Hydrolytic and oxidation metabolic conversion of bambuterol into terbutaline.

takes place, releasing the epinephrin (Figure 29) (Rautio et al., 2008; Mandell et al., 1978; Wei et al., 1978).

\section{Mixed prodrugs used in therapy}

Mixed prodrugs are latent forms with the simultaneous characteristics of bioprecursors and classic prodrugs. In other words, they present as biologically inactive molecules that need to undergo several chemical reactions (hydrolytic and/or oxyreductive) in order to be converted into their active forms (Bodor, Abdelalim, 1985; Chung et al., 2005;).

\section{Antineoplasic agents}

Capecitabine is a carbamoyl fluoropyrimidine with an antineoplasic function, which features reduced gastrointestinal toxicity and high tumor selectivity. It is a prodrug that, after three stages of biotransformation (Figure 30), creates fluorouracil, a compound with an antineoplasic function. It is quickly absorbed by the gastrointestinal system, initially undergoing hepatic bioactivation by carboxylic esterase, thus forming 5'-deoxy- 5-fluorocytidine. Cytidine deaminase, an enzyme found in several types of tissue, including tumors, subsequently converts 5'-deoxy-5-fluorocytidine into 5'-deoxy-5fluorouridine. The enzyme thymidine phosphorylase then converts 5'-deoxy-5-fluorouridine into the active drug fluorouracil. Many tissues throughout the organism contain thymidine phosphorylase. Some human carcinomas have high concentrations of this enzyme, a fact that favors the high rate of specificity of this drug (Miwa, 1998; Quinney et al., 2005; Schuller et al., 2000; Tabata et al., 2004).

\section{Reciprocal prodrugs}

Despite the fact that the classic concept of latentiation refers to compounds containing pharmacologically inactive transporter groups, this cannot be extended to what is termed the reciprocal prodrug. In this type of derivative the transporter also has a therapeutic function, as it is constituted from the chemical association between two drugs, in such a manner that one acts as the transporter for the other, thus improving the effect of both. From their development, it is possible to obtain prodrugs with different or similar 


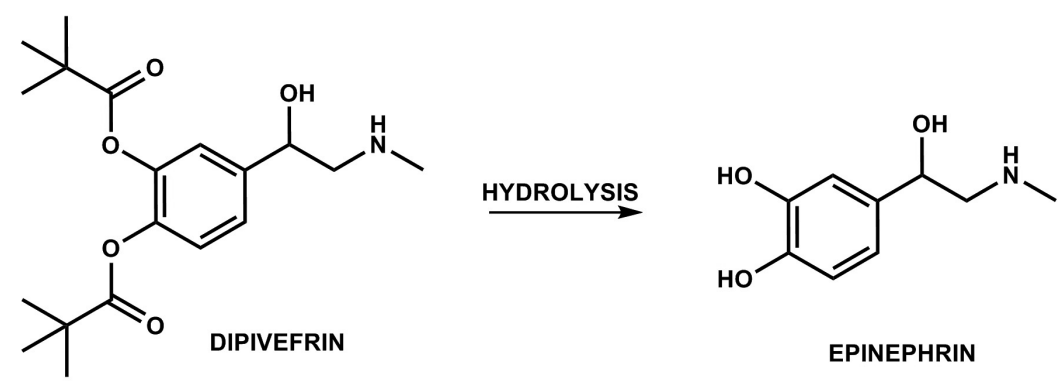

FIGURE 29 - Enzymatic conversion of dipivefrin into its active metabolite, epinephrin

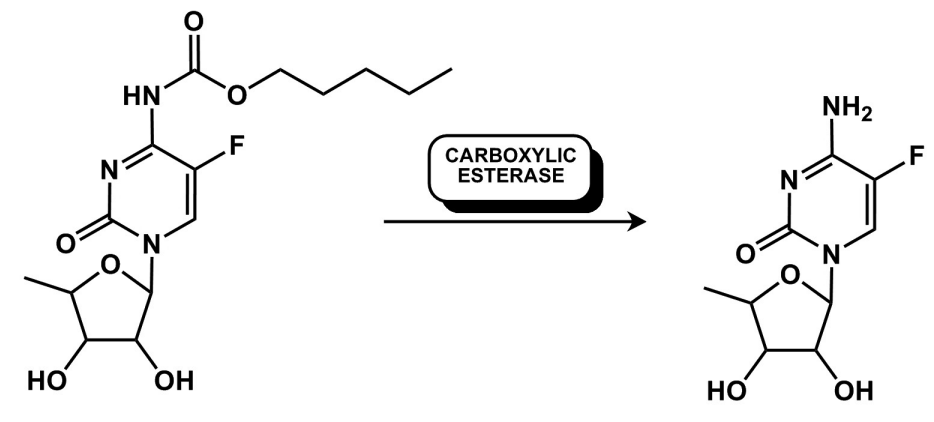

CAPECITABINE

5 '-DEOXY-5-FLUOROCYTIDINE

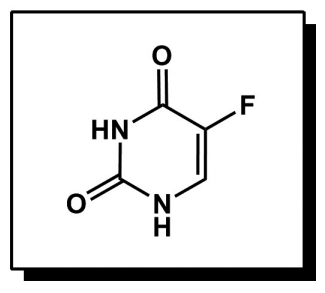

5-FLUORURACIL

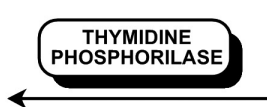<smiles>CC1OC2C(O)C(O)C(O)N2C=C1F</smiles>

5 '-DEOXY-5-FLUOROURIDINE

FIGURE 30 - Diagram of the metabolic bioactivation of capecitabine.

therapeutic functions, acting through distinctive or equal mechanisms of action (Chung et al., 2005; Chung, Ferreira, 1998; Silva et al., 2005; Singh, Sharma, 1994).

Reciprocal prodrugs differ from molecular hybrids (Barreiro, Fraga, 2008) because the former must be released through bond cleavage to perform its therapeutic effect.

\section{Antibacterial agents}

Sulfasalazine, introduced in 1942, is a highly useful prodrug, and one of the few available for the treatment of several types of chronic inflammatory intestinal diseases and rheumatoid arthritis. Through the action of intestinal azoreductases, this prodrug (Figure 31) releases, in vivo, two pharmacologically active substances, sulfapyridine and 5-aminosalicylic acid (5-ASA) (Chung et al., 2005;<smiles>O=C(O)c1cc(N=Nc2ccc(S(=O)(=O)Nc3ccccn3)cc2)ccc1O</smiles>

AZOREDUCTASES<smiles>Nc1ccc(O)c(C(=O)O)c1</smiles><smiles>Nc1ccc(S(=O)(=O)Nc2ccccn2)cc1</smiles>

FIGURE 31 - Diagram of the bioactivation of sulfasalazine through the action of azoreductases. 


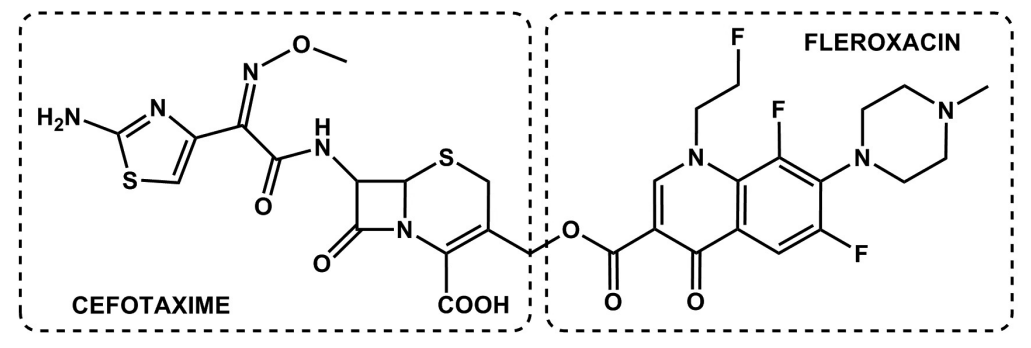

FIGURE 32 - Example of a reciprocal prodrug between fleroxacin and cefotaxine.

Freire et al., 2006; Singh, Sharma, 1994). 5-ASA is the effective component in diseases of the colon, however, after oral administration it undergoes intense absorption in the upper parts of the gastrointestinal tract, and is not locally effective on the colon (Dash, Brittain, 1998). In fact, when administered in sulfasalazine form, at least $85 \%$ of an oral dose passes intact through the stomach and small intestine (Watts, Illum, 1997).

In 1960, the idea of synthesizing antibacterial drugs with dual-function arose, by employing the reciprocal prodrug concept. One of the first attempts at producing dual-function antibacterial drugs involved binding of the central nucleus of penicillin (6-APA) with norfloxacin, with the aim of providing more powerful antibacterial agents and two mechanisms with several functions. Later, prodrugs from cephalosporins with wide-ranging fluoroquinolones were obtained. The most efficient bifunctional derivative obtained consisted of the union between fleroxacin and cefotaxine (Figure 32). This compound, called Ro-239424, featured a broad range of effectiveness and a dual-function mechanism, i.e., it possessed effectiveness against transpeptidase and bacterial DNA gyrase, due to the beta-lactams and the fluroquinolonic portions of the molecule, respectively. This compound, however, is not yet available for use in therapy (Bhanot et al., 2001).

Sultamiciline is an example of a reciprocal prodrug used in therapy. It consists of a dual ester obtained from the bond between ampicillin and sulbactam, a non-classic beta-lactams antibiotic. Besides masking the free carboxylic acid present in the structure of these compounds, thus facilitating absorption, this union is an advantage, because ampicillin is active in oral administration but inactive with beta-lactamases, while the latter is just a beta-lactamase inhibitor. After the absorption of the sultamicilin, hydrolysis of the esters takes place (Figure 33) which releases ampicillin with antibacterial function and sulbactam, capable of binding to beta-lactamase enzymes. This protects classic penicillin from beta-lactamase action . Sultamiciline is recommended for infections caused by microorganisms sensitive to the combination of ampi- cillin and sulbactam (Carneiro França, 2008). Typical recommendations are: infections of the upper and lower respiratory tracts, including sinusitis, otitis media and epiglotitis; bacterial pneumonia; infections of the urinary tract and pyelonephritis; intra-abdominal infections, including peritonitis, cholecystitis, endometritis and pelvic cellulitis; bacterial sepsis; skin, soft tissue, bone and joint infections, as well as gonococcal infections (Friedel et al., 1989; Lopez, Rivas, 1998).

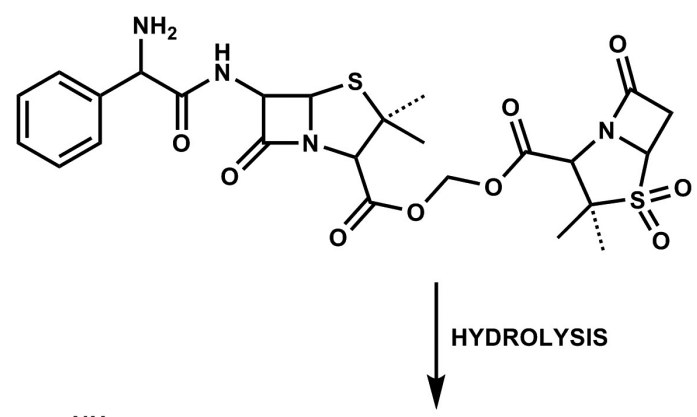

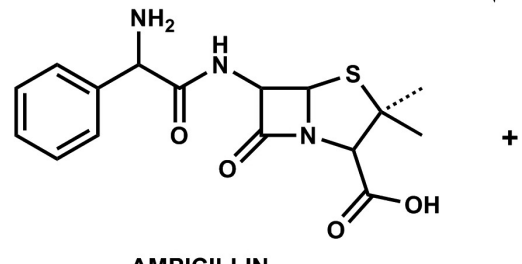

AMPICILLIN

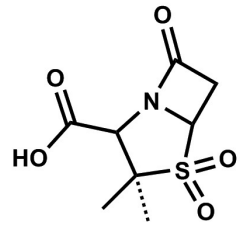

SULBACTAM
FIGURE 33 - Diagram of bioactivation of the sultamiciline prodrug.

\section{CONCLUSION}

Latentiation can be considered a tool of Pharmaceutical Chemistry that enables, in a simple fashion, improvement of the physical-chemical properties of drugs, adapting their pharmaceutical and/or pharmacokinetic characteristics, thus allowing the introduction, re-introduction or simple optimization of drugs used in therapy.

Through data found in literature, we observed that most prodrugs available for use in therapy are classic prodrugs, making up 53\% of the total analyzed, followed by bioprecursors, with $42 \%$ market share. Regarding classic 
prodrugs, despite the possibility of designing different types of hydrolysable bonds between the drug and the transporter group, it was observed that most of the agents available for use in therapy are of an ester-type bond, which is easily hydrolyzed within the organism. The main purpose of these ester derivatives is to increase bioavailability and to extend the period of effectiveness. Despite the first reciprocal prodrug compound (sulfasalazine) having been introduced into therapy in 1942, not many examples of this type of prodrug are found in clinics. On the other hand, proposals for several reciprocal prodrugs were observed in different lines of research.

From the results obtained, it was evident that the number of prodrugs introduced onto the market has increased. For example, of all the medicine approved in 2001-02, prodrugs accounted for 15\% (Stella, 2004). On the other hand, it is important to emphasize the importance of the therapeutic significance of existing prodrugs. Several classes of drugs considered to be "blockbusters", that is top-selling drugs, such as statins, antiulcerous agents, anti-hypertensive agents and antivirals feature some examples that are prodrugs, for example, sinvastatin (a hypocholesterolemic agent), omeprazol (an antiulcerous agent), enalapril (an anti-hypertensive ECA inhibitor) and acyclovir (an antiviral), respectively.

It has been further observed that antineoplasic prodrugs on the market are classified as either bioprecursors or mixed prodrugs. Despite featuring a lower level of toxicity compared to other antineoplasic agents of the same class, latentiation of drugs should be examined further for the acquisition of antineoplasic agents with greater selectivity and lower toxicity. In addition, it is important to emphasize that there is some research directed towards the acquisition of antineoplasic prodrugs using, for example, peptides as transporters or more advanced techniques, known as ADEPT (Antibody-Directed Enzyme Prodrug Therapy) or GDEPT/VDEPT (GeneVirus-Directed Enzyme Prodrug Therapy) (Chung et al., 2005), for which, derivatives have not yet been used in therapy.

Although several types of prodrugs from very distinctive classes are available for use in therapy, it can be noted that none of those mentioned are used for the treatment of neglected illnesses. However, latentiation should be explored when designing chemical entities for tropical endemic diseases, since it is not a costly method and has the potential of giving rise to therapeutically useful compounds.

Several prodrugs for the therapeutic treatment of these diseases have already been proposed and synthesized (Chung et al., 2005). In most cases, such compounds aim to increase selectivity. In 1996, for example, Chung,
1996, synthesized reciprocal prodrugs from primaquine and nitrofural (Chung et al., 2000), using dipeptidyl spacers with a scission selected by cruzipain (the exclusive enzyme of $T$. Cruzi), the purpose being to obtain potential drugs to combat American trypanosomiasis. The derivative hydroxymethylnitrofural has proven to be more active and less toxic than its prototype (Chung et al., 2003) and despite the mechanism still not having been fully understood, several aspects of it are being studied (Barbosa et al., 2007; Doriguetto et al., 2005; Guido et al., 2001a; Guido et al., 2001b; Grillo et al., 2007; Grillo et al., 2008a; Grillo et al., 2008b; Melo et al., 2007; Trossini, 2008). On the other hand, Parise-Filho et al. $(2004,2007)$ and Parise-Filho and Silveira (2001) proposed polymeric prodrugs from oxamniquine with the aim of extending its period of effectiveness and reducing the toxicity of this schistosomal agent.

Many studies and research projects are being carried out in an effort to design new prodrugs which open up new perspectives for the treatment of several diseases. However, the aim of the present study was only to present existing prodrugs used in therapy, confirming the importance of this method not only as a research tool. It was ascertained that, although current research on the latentiation of drugs explores more advanced technologies, the prodrugs available for therapy to date have mostly been based on simpler design strategies.

\section{REFERENCES}

AGUILAR, M. A.; ALTAMIRANO, L.; LEON, D. A.; FUNG, R. C.; GRILLO, A. E.; GONZALES, J. D. J.; CANALES, J. R. L.; SANCHEZ, J. C. M.; POZUELOS, J. L.; RAMIREZ, L. RIGIONNI, R.; SALGADO, J. S.; TORRES, L. VALLECILLOS, G.; ZAMBRANO, E. J.; ZEA, C. Current status of injectable hormonal contraception, with special reference to the monthly method. Adv. Contraception, Washington, v.13, n.4, p.405-417, 1997.

ALBERT, A. Chemical Aspects of Selective Toxicity. Nature Rev. Drug Discov., New Jersey, v.182, n.16, p.421-423, 1958.

ANDERSEN, R.; NIELSEN, C.; BEGTRUP, M.; STEEN, F.; BRODIN, J.; FROKJAER, S.; STEFFANSEN, B. In vitro evaluation of $\mathrm{N}$-methyl amide tripeptidomimetics as substrates for the human intestinal di-/tri-peptide transporter hPEPT1. Eur. J. Pharm. Sci., Copenhagen, v.28, n.4, p.325$335,2006$. 
ARAÚJO-JÚNIOR, N. L. C.; ATHANAZIO, D. A. Terapia de reposição hormonal e o câncer do endométrio. Cad. Saúde Pública, Rio de Janeiro, v.23, n.11, p.2613-2622, 2007.

BALBI, H. J. Chloramphenicol: A Review. Pediatrics Rev., New York, v.25, n.1, p.284-288, 2004.

BARBOSA, C. F.; OKUDA, E. S.; CHUNG, M. C.; FERREIRA, E. I.; CICARELLI, R. M. B. Rapid test for the evaluation of the activity of the prodrug hydroxymethylnitrofurazone in the processing of Trypanosoma cruzi messenger RNAs. Braz. J. Med. Biol. Res., São Paulo, v.40, n.1, p.33-39, 2007.

BARRADELL, L. B.; FAULDS, D.; MCTAVISH, D. Lansoprazole: a review of its pharmacodynamic and pharmacokinetic properties and its therapeutic efficacy in acid-related disorders. Drugs, Auckland, v.44, n.2, p.225$250,1992$.

BARREIRO, E. J.; FRAGA, C. A. M. Química medicinal: as bases moleculares da ação dos fármacos. 2.ed. Porto Alegre: Artmed, 2008. 563 p.

BATRES, E.; GOMEZ, R.; ROSENKRANS, G.; SONDHEIMER, F. Notes - Steroids. LXXVI. Synthesis of Long Chain Carboxylic Acid Esters of $17 \alpha$-Hydroxyprogesterone. $J$. Org. Chem., Washington, v.21, n.2, p.240-241, 1956.

BEAUMONT, K.; WEBSTER, R.; GARDNER, I.; DACK, $\mathrm{K}$. Design of ester prodrugs to enhance oral absorption of poorly permeable compounds: challenges to the discovery scientist. Curr. Drug Metab., Kent, v.4, n.6, p.461-485, 2003.

BECHELLI, L.P.C. Antipsicóticos de ação prolongada no tratamento de manutenção da esquizofrenia. Parte II. O manejo do medicamento, integração da equipe multidisciplinar e perspectivas com a formulação de antipsicóticos de nova geração de ação prolongada. Rev. Latino-Am. Enfermagem, Ribeirão Preto, v.11, n.4, p.507$515,2003$.

BERESFORD, R.; WARD, A. Haloperidol decanoate. A preliminary review of its pharmacodynamic and pharmacokinetic properties and therapeutic use in psychosis. Drugs, Auckland, v.33, n.1, p.31-49, 1987.

BERGAN, T. Pharmacokinetic Comparison of Oral Bacampicillin and Parenteral Ampicillin. Antimicrob. Agents and Chemother., Stockholm, v.13, n.6, p.971-974, 1978.
BHANOT, S. K.; SINGH, M.; CHATTERJEE, N. R. The chemical and biological aspects of fluoroquinolones: reality and dreams. Curr. Pharma. Design, Netherlands, v.7, n.5, p.311-335, 2001.

BIAGI, G. L.; BARBARO, A. M.; GANDOLFI, O.; GUERRA, M. C.; CANTELLI-FORTI, G. Rm values of phenols. Their relation with $\log \mathrm{P}$ values and activity. J. Med. Chem., New York, v.18, n.9, p.868-873, 1975.

BLAU, L.; MENEGON, R. F.; CHUNG, M. C. Pró-fármaco ativado por enzima, uma estratégia promissora na quimioterapia. Quim. Nova, São Paulo, v.26, n.6, p.1307$1317,2006$.

BODIN, N. O.; EKSTROM, B.; FORSGREN, U.; JALAR, L. P.; MAGNI, L.; RAMSAY, C. H.; SJOBERG, B. Bacampicillin: a New Orally Well-Absorbed Derivative of Ampicillin. Antimicrob. Agents and Chemother., Stockholm, v.8, n.5, p.518-525, 1975.

BODOR, N.; ABDELALIM, A. M. Improved delivery through biological membranes XIX: Novel redox carriers for brainspecific chemical delivery systems. J. Pharm. Sci., Kansas, v.74, n.3, p.241-245, 1985.

BRAVO, P. A. F.; NASSIF, M. C. Doença de Parkinson: terapêutica atual e avançada. Pharmacia Brasileira, v.55, p.25-29, 2006.

BUNDGAARD, H. Design of prodrugs. Amsterdam: Elsevier, $1985.360 \mathrm{p}$.

BUNDGAARD, H. Novel chemical approaches in prodrug design. Drugs, Auckland, v.16, n.1, p.443-458, 1991.

CAMPO, V. L.; CARVALHO, I. Estatinas hipolipêmicas e novas tendências terapêuticas. Quim. Nova, São Paulo, v.30, n.2, p.425-430, 2007.

CHAPMAN, T. M.; Plosker, G. L.; PERRY, C. M. Fosamprenavir: a review of its use in the management of antiretroviral therapy-naive patients with HIV infection. Drugs, Auckland, v.64, n.18, p.2101-2124, 2004.

CHAPMAN, T.; MCGAVIN, J.; NOBLE, S. Tenofovir disoproxil fumarate. Drugs, Auckland, v.63, n.18, p.15971608, 2003. 
CHUNG, M. C. Planejamento e sintese de pró-fármacos reciprocos de nitrofural e primaquina potencialmente antichagásicos. São Paulo, 1996. 196f. [Tese de Doutorado. Faculdade de Ciências Farmacêuticas. Universidade de São Paulo].

CHUNG, M. C.; FERREIRA, E. I. O processo de latenciação no planejamento de fármacos. Quim. Nova, São Paulo, v.22, n.1, p.75-84, 1998.

CHUNG, M. C.; GONÇALVES, M. F.; COLLI, W.; FERREIRA, E. I.; MIRANDA, M. T. M. Synthesis and in vitro evaluation of potential antichagasic dipeptide prodrugs of primaquine. J. Pharm. Sci., Kansas, v.86, n.10, p.1127-1131, 2000.

CHUNG, M. C.; GUIDO, R. V. C.; MARTINELLI, T. F.; GONÇALVES, M. F.; POLLI, M. C.; BOTELHO, K. C. A.; VARANDA, E. A.; COLLI, W.; MIRANDA, M. T. M.; FERREIRA, E. I. Synthesis and in vitro evaluation of potential antichagasic hydroxymethylnitrofurazone (NFOH-121): a new nitrofurazone prodrug. Bioorg. Med. Chem., São Paulo, v.11, n.22, p.4779-4783, 2003.

CHUNG, M. C.; SILVA, A. T. A.; CASTRO, L. F.; GUIDO, V. C.; NASSUTE, J. C.; FERREIRA, E. I. Latenciação e formas avançadas de transporte de fármacos. Brazilian $J$. Pharm. Sci., v.41, n.2, p.155-179, 2005.

CLERCQ, E. D. Antiviral drugs in current clinical use. J. Clin. Virol., v.30, n.2, p.115-133, 2004.

CLERCQ, E. D. Strategies in the design of antiviral drugs. Nat. Rev. Drug Discov., New Jersey, v.1, n.1, p.13-25, 2002.

COHEN, J. L.; JAO, J. Y. Enzymatic basis of ciclophosphamide activation by hepatic microsomes of the rat. J. Pharm. Exp. Ther, Boston, v.174, n.2, p.206-210, 1970.

DASH, A. K.; BRITTAIN, H. G. Mesalamine. In: BRITTAIN, H.G., (Eds.). Analytical profiles of drug substances and excipients. New York: Academic Press, 1998. v.25, p.209242.

DHARESHWAR, S. S. Prodrugs of Alcohols and Phenols. In: STELLA, V. J.; BORCHARDT, R. T.; HAGEMAN, M. J.; OLIYAI, R.; MAAG, R.; TILEY, J. W. Prodrugs: challenges and rewards. Part 1. New York: Springer, 2007. p.31-100.
DORIGUETTO, A. C.; SILVA, C. H. T. P.; ELLENA, J.; TROSSINI, G. H. G.; CHIN, C. M.; FERREIRA, E. I. 5-Nitro-2-furaldehyde N-(hydroxymethyl)semicarbazone. Acta Crystallogr. Sect. C: Cryst. Struct. Commun., Boston, v.E61, n.7, p.2099-2101, 2005.

EHRNEBO, M.; NILSSON, S.; BOERUS, L. O. Pharmacokinetics of ampicillin and its prodrugs bacampicillin and pivampicillin in man. J. Pharmacokinet. Pharmacodyn., Stockholm, v.7, n.5, p.429-451, 1979.

ETTMAYER, P.; AMIDON, G. L.; CLEMENT, B.; TESTA, B. Lessons learned from marketed and investigational prodrugs. J. Med. Chem., New York, v.47, n.10, p.23932404, 2004.

FATIMA, A.; BAPTISTELLA, L. H. B.; PILLI, R. A.; MODOLO, L. V. Ácidos siálicos - da compreensão do seu envolvimento em processos biológicos ao desenvolvimento de fármacos contra o agente etiológico da gripe. Quim. Nova, São Paulo, v.28, n.2, p.306-316, 2005.

FERREIRA, S. H. A bradykinin-potentiating factor (bpf) present in the venom of Bothrops jararaca. Brit. J. Pharmacol., England, v.24, n.1, p.163-169, 1965.

FINLEY, J. B.; ATIGADDA, V. R.; DUARTE, F.; ZHAO, J. J.; BROUILLETTE, W. J.; AIR, G. M.; LUO, M. Novel aromatic inhibitors of influenza virus neuraminidase make selective interactions with conserved residues and water molecules in the active site. J. Mol. Biol., Ocklahoma, v.293, n.5, p.1107-1119, 1999.

CARNEIRO FRANÇA, F. F. A. Dicionário Terapêutico Guanabara 2008/2009. 15.ed. Rio de Janeiro: Guanabara Koogan, 2008. 443 p.

FREIRE, A. C.; PODCZECK, F.; SOUSA, J.; VEIGA, F. Liberação específica de fármacos para administração no cólon por via oral. I - O cólon como local de liberação de fármacos. Rev. Bras. Cien. Farm., São Paulo, v.42, n.3, p.319-335, 2006.

FRIEDEL, H. A.; CAMPOLI-RICHARDS, D. M.; GOA, K. L. Sultamicillin. A review of its antibacterial activity, pharmacokinetic properties and therapeutic use. Drugs, Auckland, v.37, n.4, p.491-522, 1989. 
FRIEDMAN, D. I.; AMIDON, G. L. Passive and CarrierMediated Intestinal Absorption Components of Two Angiotensin Converting Enzyme (ACE) Inhibitor Prodrugs in Rats: Enalapril and Fosinopril. Pharm. Res., Michigan, v.6, n.12, p.1043-1047, 1989.

FRIIS, G. J.; BUNDGAARD, H. Design and application of prodrugs. In: KROGSGAARD-LARSEN, P.; LILJEFORS, T; MADSEN, U. A textbook of drug design and development. Amsterdam: Harwood Academic, 1996. 543 p.

FUCHS, T. Case Study - Cefditoren Pivoxil: An oral prodrug of Cefditoren. In: STELLA, V. J.; BORCHARDT, R. T.; HAGEMAN, M. J.; OLIYAI, R.; MAAG, R.; TILEY, J. W. Prodrugs: challenges and rewards Part 1. New York: Springer, 2007. p.133-187.

GALLANT, J. E.; DERESINSKI, S. Tenofovir disoproxil fumarate. Clin. Infect. Dis., Chicago, v.37, n.7, p.944-950, 2003.

GHISELLI, G.; JARDIM, W. F. Interferentes endócrinos no ambiente. Quim. Nova, São Paulo, v.30, n.3, p.695-706, 2007.

GRILLO, R.; MELO, N. F. S.; FRACETO, L. F.; BRASILEIRA, C. P. R. F.; BRITO, C. L.; TROSSINI, G. H. G.; MENEZES, C. M. S.; FERREIRA, E. I.; MORAES, C. M. Caracterização físico-química de complexo de inclusão entre hidroximetilnitrofurazona e hidroxipropil-b-ciclodextrina. Quim. Nova, São Paulo, v.31, n.2, p.290-295, 2008.

GRILLO, R.; MELO, N. F. S.; MORAES, C. M.; De LIMA, R.; MENEZES, C. M. S.; FERREIRA, E. I.; ROSA, A. H.; FRACETO, L. F. Study of the interaction between hydroxymethylnitrofurazone and 2-hydroxypropyl- $\beta$ cyclodextrin. J. Pharm. Biomed. Anal., Baltimore, v.47, n.2, p.295-302, 2008.

GRILLO, R.; MELO, N. F. S.; MORAES, C. M.; ROSA, A. H.; ROVEDA, J. A. F.; MENEZES, C. M. S.; FERREIRA, E. I.; FRACETO, L. F. Hydroxymethylnitrofurazone:Dimethyl$\beta$-cyclodextrin Inclusion Complex: A Physical-Chemistry Characterization. J. Biol. Physics, Netherlands, v.33, n.5-6, p.445-453, 2007.
GRISKEVICIUS, L.; YASAR, U.; SANDBERG, M.; HIDESTRAND, M.; ELIASSON, E.; TYBRING, G.; HASSAN, M.; DAHL, M. L. Bioacivation of ciclophosphamide: the role of CYP2C enzymes. Eur. J. Clin. Pharmacol., Berlin, v.59, n.2, p.103-109, 2003.

GUIDO, R. V. C.; FERREIRA, E. I.; NASSUTE, J. C.; VARANDA, E. A.; CHIN, C. M. Diminuiçäo da atividade mutagênica do pró-fármaco NFOH-121 em relaçäo ao nitrofural (nitrofurazona). Rev. Cien. Farm., São Paulo, v.22, n.2, p.319-333, 2001.

GUIDO, R. V. C.; VARANDA, E. A.; FERREIRA, E. I.; CHIN, C. M. Estudo do potencial mutagênico do pró-fármaco antichagásico hidroximetilnitrofural. Rev. Cien. Farm., São Paulo, v.22, n.2, p.345-425, 2001.

GUO, A.; HU, P.; BALIMANE, P. V.; LEIBACH, F. H.; SINKO, P. J. Interactions of a nonpeptide drug, valacyclovir, with the human intestinal peptide transporter (hPEPT1) expressed in a mammalian cell line. J. Pharmacol. Exp. Ther., New Jersey, v.289, n.1, p.448-454, 1999.

HAN, H. K.; AMIDON, G. L. Targeted prodrug design to optimize drug delivery. AAPS Pharm. Sc., New York, v.2, n.1, p.48-58, 2000.

HARPER, N. J. Drug latentiation. J. Med. Chem., New York, v.1, n.5, p.467-500, 1959.

HAYDEN, F. G., ATMAR, R. L.; SCHILLING, M.; JOHNSON, C.; PORETZ, D.; PAAR, D.; HUDSON, L.; WARD, P.; MILLS, R. G. Use of the Selective Oral Neuraminidase Inhibitor Oseltamivir to Prevent Influenza. New Eng. J. Med., England, v.341, n.18, p.1336-1343, 1999.

HE, G.; MASSARELLA, J.; WARD, P. Clinical pharmacokinetics of the prodrug Oseltamivir and its active metabolite Ro 640802. Clin. Pharmacokinet., California, v.37, n.6, p.471484, 1999.

IMS - Intercontinental Marketing Services. IMS Health Reports 2009 First-Quarter Results. Available at: $<$ http://www. imshealth.com/portal/site/imshealth/menuitem.a46c6d4df 3db4b3d88f611019418c22a/?vgnextoid=fd987976c22d0 210VgnVCM100000ed152ca2RCRD\&vgnextchannel=4 1a67900b55a5110VgnVCM10000071812ca2RCRD\&vg nextfmt $=$ default $>$. Accessed on: 02 fev. 2009. 
JANN, M. W.; ERESHEFSKY, L.; SAKLAD, S. R. Clinical pharmacokinetics of the depot antipsychotics. Clin. Pharmacokinet., Ohio, v.10, n.4, p.315-333, 1985.

KOROLKOVAS, A.; BURCKHALTER, J. H. Química Farmacêutica. 2.ed. Rio de Janeiro: Guanabara Koogan, $1988.733 \mathrm{p}$.

LARSEN, S. W.; ANKERSEN, M.; LARSEN, C. Kinetics of degradation and oil solubility of ester prodrugs of a model dipeptide (Gly-Phe). Eur. J. Pharm. Sci., Copenhagen, v.22, n.5, p.399-408, 2004.

LEMKE, T. L.; WILliAMS, D. A. Foye's Principles of medicinal chemistry. 6.ed. Philadelphia: Lippincott Williams \& Wilkins, 2008. 1209 p.

LIEDERER, B. M.; BORCHARDT, R. T. Enzymes involved in the bioconversion of ester-based prodrugs. J. Pharm. Sci., Kansas, v.95, n.6, p.1177-1195, 2006.

LINDBERG, P.; NORDBERG, P.; ALMINGER, T.; BRAENDSTROEM, A.; WALLMARK, B. The mechanism of action of the antisecretory agent omeprazole. J. Med. Chem., Washington, v.29, n.8, p.1327-1329, 1986.

LOPEZ, E. L.; RIVAS, N. A. Clinical use of sultamicillin (ampicillin/sulbactam) in children. Pediatric Infect. Dis., Dallas, v.17, n.3, p.S12-S14, 1998.

MANDELL, A. I.; STENTZ, F.; KITABCHI, A. E. Dipivalyl epinephrine: a new pro-drug in the treatment of glaucoma. Ophthalmology, Boston, v.85, n.3, p.268-275, 1978.

MAURO, V. F. Clinical pharmacokinetics and practical applications of simvastatin. Clin. Pharmacokinet., Ohio, v.24, n.3, p.195-202, 1993.

MELO, N. F. S.; GRILLO, R.; MORAES, C. M.; BRITO, C. L.; TROSSINI, G. H. G.; MENEZES, C. M. S.; FERREIRA, E. I.; ROSA, A. H.; FRACETO, L. F. Preparação e caracterização inicial de complexo de inclusão entre nitrofurazona e 2-hidroxipropil-ciclodextrina. Rev. Cien. Farm. Bas. Aplic., Rio de Janeiro, v.28, n.1, p.35-44, 2007.

MISHELL, D. R. Pharmacokinetics of depot medroxyprogesterone acetate contraception. J. Reprod. Med., Los Angeles, v.41, n.5, p.381-390, 1996.
MIWA, M.; Design of a novel oral fluoropyrimidine carbamate, capecitabine, which generates 5-fluorouracil selectively in tumours by enzymes concentrated in human liver and cancer tissue. Eur. J. Cancer, Cambridge, v.34, n.8, p.1274-1281, 1998.

OTTO, M. J. New nucleoside reverse transcriptase inhibitors for the treatment of HIV infections. Curr. Opin. Pharmacol., v.4, n.5, p.431-436, 2004.

PARISE-FILHO, R.; ARAÚJO, A. A. S.; SANTOS-FILHO, M.; MATOS, J. R.; SILVEIRA, M. A. B; BRANDT, C. A. Thermoanalytical characterization of potentially schistosomicide polymeric derivatives. J. Therm. Anal. Cal. v.75, n.2, p.487-494, 2004.

PARISE-FILHO, R.; MENEZES, C. M. S., PINTO, P. L. S.; PAUlA, G. A., BRANDT, C. A.; SILVEIRA, M. A. B. Design, synthesis, and in vivo evaluation of oxamniquine methacrylate and acrylamide prodrugs. Bioorg. Med. Chem. São Paulo, v.15, n.3, p.1229-1236, 2007.

PARISE-FILHO, R.; SILVEIRA, M. A. B. Panorama atual da esquistossomíase no mundo. Rev. Bras. Cien. Farm., São Paulo, v.37, n.2, p.123-135, 2001.

PASQUALINI, J. R. Progestins: Present and future. J. Steroid Biochem. Molec. Biol., Boston, v.59, n.5-6, p.357-363, 1996.

PATANI, G. A.; LAVOIE, E. J. Bioisosterism: A rational approach in drug design. Chem. Rev., Washington, v.96, n.8, p.3147-3176, 1996.

PATRICK, G. L. An Introduction to Medicinal Chemistry. 3.ed. New York: Oxford University Press, 2005. 713 p.

PERRY, C. M.; BROGDEN, R. N. Cefuroxime axetil: A review of its antibacterial activity, pharmacokinetic properties and therapeutic efficacy. Drugs, Auckland, v.52, n.1, p.125-158, 1996.

PETROW, V. Contraceptive progestagens. Chem. Rev., Washington, v.70, n.6, p.713-726, 1970.

POWELL, D. A.; NAHATA, N. C. Chloramphenicol: new perspectives on an old drug. Drug Intel. Clin. Pharm., Boston, v.16, n.4; p.295-300, 1982. 
QUINNEY, S. K.; SANGHANI, S. P.; DAVIS, W. I.; HURLEY, T. D.; SUN, Z.; MURRY, D. J.; BOSRON, W. F. Hydrolysis of Capecitabine to 5'-Deoxy-5-fluorocytidine by Human Carboxylesterases and Inhibition by Loperamide. $J$. Pharmacol. Exp. Ther., Los Angeles, v.313, n.3, p.1011$1016,2005$.

RAUTIO, J.; KUMPULAINEN, H.; HEIMBACH, T.; OLIYAI, R.; OH, D.; JÄRVINEN, T.; SAVOLAINEN, J. Prodrugs: design and clinical applications. Nat. Rev. Drug Discov., New Jersey, v.7, n.3, p.255-270, 2008.

ROBINSON, M. Review Article: The pharmacodynamics and the pharmacokinetics of proton pump inhibitors - overview and clinical implications. Aliment. Pharmacol. Ther., Ocklahoma City, v.20, n.6, p.1-10, 2004.

ROCHE, V. F. Antihyperlipidemic Statins: A self-contained, clinically relevant medicinal chemistry lesson. Am. J. Pharm. Educ., Washington, v.69, n.4, p.546-561, 2005.

ROCHE, V. F. The chemically elegant próton pump inhibitors. Am. J. Pharm. Educ., Washington, v.70, n.5, p.101-111, 2006.

ROONEY, P. H.; TELFER, C.; MCFADYEN, M. C.; MELVIN, W. T.; MURRAY, G. I. The role of cytochrome P450 in cytotoxic bioactivation: future therapeutic directions. Curr. Cancer Targ., Aberdeen, v.4, n.3, p.257-265, 2004.

ROSENBORG, L.; LARSSON, P.; NYBERG, L. Pharmacokinetics of bambuterol during oral administration of plain tablets and solution to healthy adults. Brit. J. Clin. Pharmacol., England, v.49, n.3, p.199-206, 2001.

SANTOS, C. Ciclização Intramolecular: uma estratégia promissora no desenvolvimento de pró-fármacos. Rev. Bras. Cien. Farm., São Paulo, v.44, n.3, p.349-360, 2008.

SANTOS, V. M. R.; DONNICI, C. L.; COSTA, J. B. N.; CAIXEIRO, J. M. R. Compostos organofosforados pentavalentes: histórico, métodos sintéticos de preparação e aplicações como inseticidas e agentes antitumorais. Quim. Nova, São Paulo, v.30, n.1, p.159-170, 2007.

SHAN, D.; NICOLAOU, M. G.; BORCHARDT, R. T.; WANG, B. Prodrug strategies based on intramolecular cyclization reactions. J. Pharm. Sci., Kansas, v.86, n.7, p.765-767, 2000 .
SHIN, J. M.; CHO, Y. M.; SACHS, G. Chemistry of covalent inhibition of the gastric $(\mathrm{H}+, \mathrm{K}+)$-ATPase by proton pump inhibitors. J. Am. Chem. Soc., California, v.126, n.25, p.7800-7811, 2004.

SHULlER, J.; CASSIDY, J.; DUMONT, E.; ROOS, B.; DURSTON, S.; BANKEN, L.; UTOH, M.; MORI, K.; WEIDEKAMM, E.; REIGNER, B. Preferential activation of capecitabine in tumor following oral administration to colorectal cancer patients. Cancer Chemother. Pharmacol., Berlin, v.45, n.4, p.291-297, 2000.

SILVA, A. T. A.; CASTRO, L. F.; GUIDO, R. V. C.; CHUNG, M. C.; FERREIRA, E. I. Advances in Prodrug Design. MiniRev. Med. Chem., Netherlands, v.5, n.10, p.893-914, 2005.

SIMPSON, D., LYSENG-WILLIAMSON, K. A. Famciclovir: a review of its use in herpes zoster and genital and orolabial herpes. Drugs, Auckland, v.66, n.18, p.2397-2416, 2006.

SINGH, G.; SHARMA, P. D. Mutual prodrugs : a recent trend in prodrug design. Indian J. Pharm. Sci., Mumbai, v.56, n.3, p.69-79, 1994.

SJÖVALL, J.; MAGNI, L.; BERGAN, T. Pharmacokinetics of Bacampicillin Compared with Those of Ampicillin, Pivampicillin, and Amoxycillin. Antimicrob. Agents Chemother., Stockholm, v.13, n.1, p.90-96, 1978.

STEFANO, A. D.; SOZIO, P.; CERASA, L. S. Antiparkinson prodrugs. Molecules, Basel, v.13, n.1, p.46-68, 2008.

STEFFANSEN, B.; NIELSEN, C. U.; BRODIN, B.; ERIKSSON, A. H.; ANDERSEN, R.; FROKJAER, S. Intestinal solute carriers: an overview of trends and strategies for improving oral drug absorption. Eur. J. Pharm. Sci., Copenhagen, v.21, n.1, p.3-16, 2004.

STEINGRIMSDOTTIR, H.; GRUBER, A.; PALM, C.; GRIMFORS, G.; KALIN, M.; EKSBORG, S. Bioavailability of Aciclovir after oral administration of Aciclovir and its prodrug Valaciclovir to patients with leucopenia after chemotherapy. Antimicrob. Agents Chemother, Stockholm, v.44, n.1, p.207-209, 2000.

STELLA, V. J. Prodrugs as therapeutics. Exp. Opin. Therap. Pat., Kansas, v.14, n.3, p.277-280, 2004. 
STELLA, V. J.; CHARMAN, W. N.; NARINGREKAR, V. H. Prodrugs. Do they have advantages in clinical practice? Drugs, Auckland, v.29, n.5, p.455-473, 1985.

STELLA, V. J.; NTI-ADDAE, K. W. Prodrug strategies to overcome poor water solubility. Adv. Drug Deliv. Rev., Kansas, v.59, n.7, p.677-694, 2007.

STELLA, V.; BORCHARDT, R. T.; HAGEMAN, M. J.; OliYAI, R.; MAAG, H.; TILlEY, J. W. Prodrugs: Challenges and Rewards. New York: Springer, 2007. $1470 \mathrm{p}$.

SUGAWARA, M.; HUANG, W.; FEI, Y. J.; LEIBACH, F. H.; GANAPATHY, V.; GANAPATHY, M. E. Transport of valganciclovir, a ganciclovir prodrug, via peptide transporters PEPT1 and PEPT2. J. Pharm. Sci., Kansas, v. 89 , n. 6, p. 781-789, jun. 2000.

TABATA, T.; KATOH, M.; TOKUDOME, S.; NAKAJIMA, M.; YOKOI, T. Identification of the cytosolic carboxylesterase catalyzing the 5'-deoxy-5-fluorocytidine formation from capecitabine in human liver. Drug Metab. Disp., Lund, v.32, n.10, p.1103-1110, 2004.

TAVARES, W. Manual de antibióticos e quimioterápicos antiinfecciosos. 3.ed. Rio de Janeiro: Atheneu, 2001. $1216 \mathrm{p}$.

TAYLOR, M. D. Improved passive oral drug delivery via prodrugs. Adv. Drug Deliv. Rev., Kansas, v.19, n.2, p.131148, 1996.

TESTA, B. Prodrug research: futile or fertile? Biochem. Pharmacol., Washington, v.68, n.11, p.2097-2106, 2004.

THOMSEN, A. E.; FRIEDRICHSEN, G. M.; SORENSEN, A. H.; ANDERSEN, R.; NIELSEN, C. U.; BRODIN, B.; BEGTRUP, M.; FROKJAER, S.; STEFFANSEN, B. Prodrugs of purine and pyrimidine analogues for the intestinal di/tri-peptide transporter PeptT1: affinity for HPept-T1 in Caco-2 cels, drug release in aqueous media an in vitro metabolism. J. Control. Rel., Copenhagen, v.86, n.2-3, p.279-292, 2003.

THOMSEN, A.; CHRISTENSEN, M. S.; BAGGER, M.; STEFFANSEN, S. Acyclovir prodrug for the intestinal di/tri-peptide transporter PEPT1: comparison of in vivo bioavailability in rats and transport in Caco-2 cells. Eur. J. Pharm. Sci., Copenhagen, v.23, n.4-5, p.319-325, 2004.
TROSSINI, G. H. G. Antichagásicos Potenciais: busca racional de compostos com ação seletiva pela cruzaína. São Paulo, 2008. 215f. [Tese de Doutorado. Faculdade de Ciências Farmacêuticas. Universidade de São Paulo].

TUNEK, A.; SVENSSON, L. A. Bambuterol, a carbamate ester prodrug of terbutaline, as inhibitor of cholinesterases in human blood. Drug Metab. Disp., Lund, v.16, n.5, p.759764,1988

VABENO, J.; NIELSEN, C. U.; INGEBRIGTSEN, T.; LEJON, T.; STEFFANSEN, B.; LUTHMAN, K. Dipeptidomimetic ketomethylene isosteres as pro-moieties for drug transport via the human intestinal di-/tripeptide transporter hPEPT1: design, synthesis, stability, and biological investigations. J. Med. Chem., New York, v.47, n.19, p.4755-4765, 2004.

VIEGAS-JUNIOR, C.; BOLZANI, V. S.; BARREIRO, E. J. Os produtos naturais e a química medicinal moderna. Quim. Nova, São Paulo, v.29, n.2, p.326-337, 2006.

WATTS, P. J.; ILLUM, L. Colonic drug delivery. Drug Dev. Ind. Pharm. Nottingham, v.23, n.9, p.893-913, 1997.

WEI, C. P.; ANDERSON, J. A.; LEOPOLD, I. Ocular absorption and metabolism of topically applied epinephrine and a dipivalyl ester of epinephrine. Investig. Ophthal. Vis. Sci., Houston, v.17, n.1, p.315-321, 1978.

WERMUTH, C. G. Designing prodrugs and bioprecursors Carrier prodrugs. In: JOLLE, G.; WOOLDRIGE, K. R. M. Drug Design: Fact or Fantasy? London: Academic Press, 1984. $543 \mathrm{p}$.

WERMUTH, C. G. Designing prodrugs and bioprecursors. In: WERMUTH, C. G. The practice of medicinal chemistry. 2.ed. London: Academic Press, 2006. p.561-585.

WIRE, M. B., SHELTON, M. J., STUdENBERG, S. Fosamprenavir: clinical pharmacokinetics and drug interactions of the amprenavir prodrug. Clin. Pharmacokinet., Ohio, v.45, n.2, p.137-168, 2006.

Received for publication on $01^{\mathrm{ft}}$ July 2009 Accepted for publication on $10^{\text {th }}$ December 2009 